\title{
Future permafrost conditions along environmental gradients in Zackenberg, Greenland
}

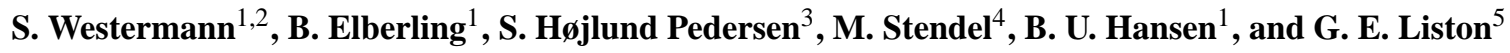 \\ ${ }^{1}$ Center for Permafrost (CENPERM), Department of Geosciences and Natural Resource Management, \\ University of Copenhagen, Øster Voldgade 10, 1350 Copenhagen K., Denmark \\ ${ }^{2}$ Department of Geosciences, University of Oslo, P.O. Box 1047, Blindern, 0316 Oslo, Norway \\ ${ }^{3}$ Department of Bioscience - Arctic Research Centre, Aarhus University, Frederiksborgvej 399, 4000 Roskilde, Denmark \\ ${ }^{4}$ Danish Climate Centre - Danish Meteorological Institute, Lyngbyvej 100, 2100 Copenhagen, Denmark \\ ${ }^{5}$ Cooperative Institute for Research in the Atmosphere, Colorado State University, 1375 Campus Delivery, Fort Collins, \\ CO 80523-1375, USA
}

Correspondence to: B. Elberling (be@ign.ku.dk)

Received: 14 May 2014 - Published in The Cryosphere Discuss.: 16 July 2014

Revised: 25 March 2015 - Accepted: 26 March 2015 - Published: 17 April 2015

\begin{abstract}
The future development of ground temperatures in permafrost areas is determined by a number of factors varying on different spatial and temporal scales. For sound projections of impacts of permafrost thaw, scaling procedures are of paramount importance. We present numerical simulations of present and future ground temperatures at $10 \mathrm{~m}$ resolution for a $4 \mathrm{~km}$ long transect across the lower Zackenberg valley in northeast Greenland. The results are based on stepwise downscaling of future projections derived from general circulation model using observational data, snow redistribution modeling, remote sensing data and a ground thermal model. A comparison to in situ measurements of thaw depths at two CALM sites and near-surface ground temperatures at 17 sites suggests agreement within $0.10 \mathrm{~m}$ for the maximum thaw depth and $1{ }^{\circ} \mathrm{C}$ for annual average ground temperature. Until 2100 , modeled ground temperatures at $10 \mathrm{~m}$ depth warm by about $5^{\circ} \mathrm{C}$ and the active layer thickness increases by about $30 \%$, in conjunction with a warming of average near-surface summer soil temperatures by $2^{\circ} \mathrm{C}$. While ground temperatures at $10 \mathrm{~m}$ depth remain below $0{ }^{\circ} \mathrm{C}$ until 2100 in all model grid cells, positive annual average temperatures are modeled at $1 \mathrm{~m}$ depth for a few years and grid cells at the end of this century. The ensemble of all $10 \mathrm{~m}$ model grid cells highlights the significant spatial variability of the ground thermal regime which is not accessible in traditional coarse-scale modeling approaches.
\end{abstract}

\section{Introduction}

The stability and degradation of permafrost areas are extensively discussed regarding future climate changes as potentially important source of greenhouse gases (Schuur et al., 2008, 2009; Elberling et al., 2010, 2013), infrastructure stability (Wang et al., 2003, 2006) and farming potential (Mick and Johnson, 1954; Merzlaya et al., 2008). Depending on the emission scenario, future projections based on coarse-scale general circulation models (GCMs) suggest a loss of 30 to $70 \%$ of the current permafrost extent by 2100 , in conjunction with a significant deepening of the active layer in the remaining areas (Lawrence et al., 2012). However, such projections are based on the modeled evolution of coarse-scale grid cells which may not represent significantly smaller variability of environmental factors governing the thermal regime typical for many permafrost landscapes. Hence, a detailed impact assessment of the thermal regime remains problematic, which precludes sound projections of future greenhouse gas emissions from permafrost areas.

Regional climate models (RCMs) facilitate downscaling of GCM output to scales of several kilometers so that, for example, regional precipitation patterns and topographyinduced temperature gradients are much better reproduced. Based on RCM output, projections of the future ground thermal regime have been performed for a number of permafrost regions, e.g., northeast Siberia $(50 \mathrm{~km}$ resolution, 
Stendel et al., 2007), Greenland (25 km resolution, Daanen et al., 2011) and Alaska ( $2 \mathrm{~km}$ resolution, Jafarov et al., 2012). While this constitutes a major improvement, many processes governing the ground thermal regime vary strongly at even smaller spatial scales so that the connection between model results and ground observations is questionable. In high-Arctic and mountain permafrost areas exposed to strong winds, redistribution of blowing snow can create a pattern of strongly different snow depths on distances of a few meters. Since snow is an effective insulator between ground and atmosphere (Goodrich, 1982), a distribution of ground temperatures with a range between average maximum and minimum temperatures of $5^{\circ} \mathrm{C}$ and more is created (e.g., Gisnås et al., 2014), which is of a similar order of magnitude to the projected increase of near-surface air temperatures in many polar areas. Consequently, the susceptibility to climate change can display a dramatic variability on local scales and permafrost degradation can occur significantly earlier in parts of a landscape than suggested by coarse-scale modeling. Furthermore, the thermal properties and cryostratigraphy of the ground can be highly variable as a result of geomorphology, vegetation and hydrological pathways, with profound implications for the thermal inertia and thus the dynamics of permafrost degradation. In a modeling study for southern Norway, Westermann et al. (2013) highlight that nearsurface permafrost in bedrock areas disappears within a few years after the climatic forcing crosses the thawing threshold, while near-surface permafrost is conserved for more than 2 decades in areas with high organic and ground ice contents and/or a dry, insulating surface layer. In addition, the soil carbon content in Arctic landscapes is unevenly distributed (Hugelius et al., 2013), and greenhouse gas emissions from localized carbon-rich hotspots can contribute a significant part to the landscape signal (e.g., Walter et al., 2006; Mastepanov et al., 2008). Therefore, both the carbon stocks and the physical processes governing permafrost evolution must be understood at the appropriate spatial scales to facilitate improved predictions of the permafrost-carbon feedback.

In recent years, modeling schemes capable of computing the ground thermal regime at significantly higher spatial resolutions of 10 to $30 \mathrm{~m}$ have been developed and applied in complex permafrost landscapes (e.g., Zhang, 2013; Zhang et al., 2012, 2013; Fiddes and Gruber, 2012, 2014; Fiddes et al., 2015). These approaches can capture smallscale differences in altitude, aspect and exposition, as well as in surface and subsurface properties, but the redistribution of snow through wind drift is only included in a simplified way through precipitation correction factors (Fiddes et al., 2015; Zhang et al., 2012). On the other hand, dedicated snow redistribution models of various levels of complexity exist (e.g., Winstral et al., 2002; Lehning et al., 2006) with which the pattern and evolution of snow depths can be simulated.

In this study we make use of such an approach, the deterministic snow modeling system MicroMet/SnowModel (Liston and Elder, 2006a, b), to achieve high-resolution simula- tions of the ground thermal regime at the Zackenberg permafrost observatory in northeast Greenland (Meltofte et al., 2008) until 2100. MicroMet/SnowModel is employed as part of a sequential downscaling procedure, including the RCM HIRHAM5 (Christensen et al., 1996) and the ground thermal model CryoGrid 2 (Westermann et al., 2013). With a spatial resolution of $10 \mathrm{~m}$, the effect of snow distribution patterns and different subsurface and surface properties on ground temperatures can be accounted for. The study aims to fill the gap between the coarse- and the point-scale modeling studies on the future ground thermal regime which are available for the Zackenberg valley so far. The $25 \mathrm{~km}$ scale, Greenlandwide assessment of Daanen et al. (2011) puts Zackenberg in the zone of "high thaw potential" until the end century, with modeled ground temperatures of -5 to $-2.5^{\circ} \mathrm{C}$ and an active layer thickness of 0.5 to $0.75 \mathrm{~m}$ for the period 2065 2075. However, the detailed point-scale study by Hollesen et al. (2011) suggests a future active layer thickness of 0.8 to $1.05 \mathrm{~m}$ for a site with average soil moisture conditions which are not representative of many other sites found in the $\mathrm{Za}$ ckenberg valley, such as the wetlands. Extending this earlier work, we present simulations for a $4 \mathrm{~km}$ transect cutting across typical vegetation zones in the lower parts of Zackenberg valley which allow estimating the range of ground thermal conditions that could be encountered until the end of the century.

\section{The Zackenberg site}

Zackenberg is located in northeast Greenland at $74^{\circ} 30^{\prime} \mathrm{N}$, $20^{\circ} 30^{\prime} \mathrm{W}$ (Fig. 1). Zackenberg valley is a wide lowland valley dominated by Quaternary non-calcareous sediments with significant periglacial activity and continuous permafrost (Elberling et al., 2004, 2008), with a mean annual air temperature of $-9.5^{\circ} \mathrm{C}$ (1996-2007) according to Elberling et al. (2010). Maximum active layer thickness varies from $40 \mathrm{~cm}$ to more than $2 \mathrm{~m}$ and has increased significantly by $0.8 \mathrm{~cm}$ to $1.5 \mathrm{~cm}$ per year between 1996 and 2012 (Elberling et al., 2013), which has been determined at two sites (denoted ZeroCalm 1 and 2, Fig. 1) of the Circumpolar Active Layer Monitoring (CALM) program (Brown et al., 2000).

From the hilltops towards the depressions, an increase in soil water content is seen from dry to wet conditions at the foot of the slopes due to snowmelt water being released during large parts of the summer. Roughly one-third of the lowland area in Zackenberg is poorly drained. Given the low summer precipitation, water availability during the growing season is mainly controlled by the location of large snow patches melting during the growing season, resulting in the distinct vegetation zonation around these.

The topography, landscape forms and wind direction are the main factors controlling both water drainage and snow distribution. These patterns are found on both a landscape scale and a small scale (100-200 m) and can therefore be il- 

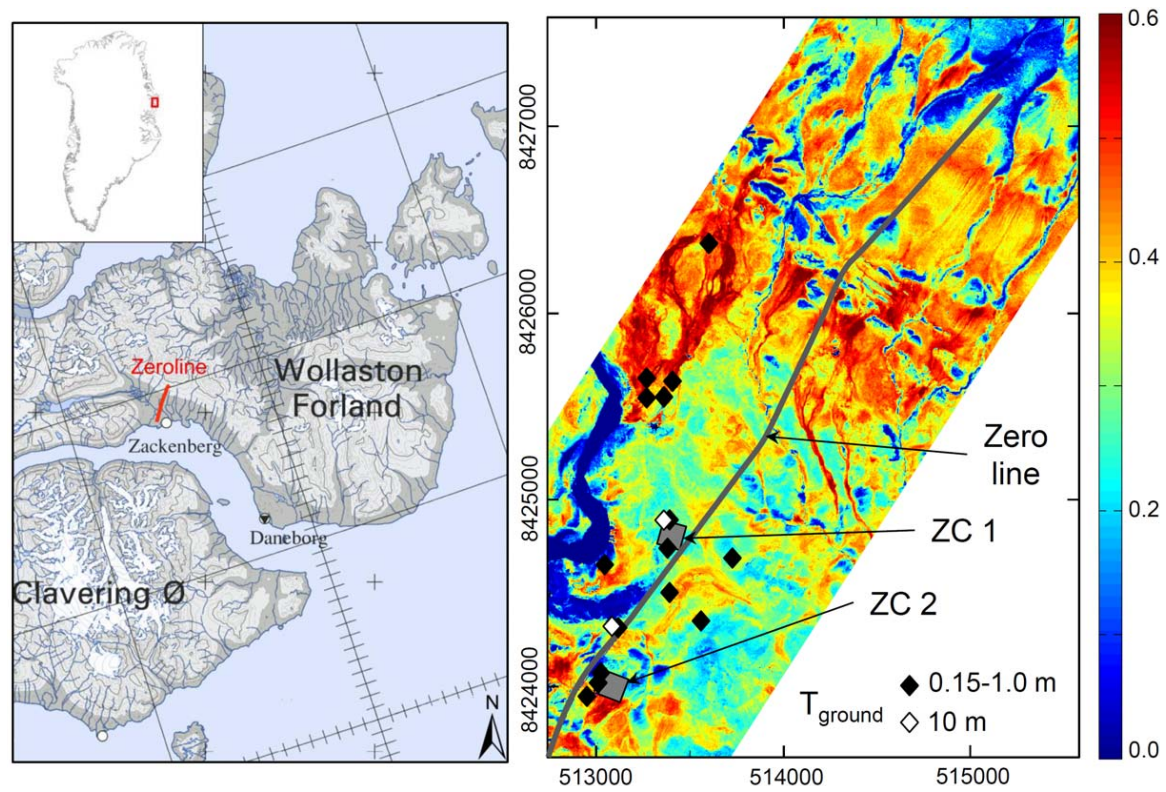

Figure 1. Left: location of the Zackenberg site and ZERO-line in Greenland. Right: NDVI image (derived from a multi-spectral Quickbird 2 image from 7 July 2011) of the modeled part of ZERO-line, with the CALM sites ZeroCalm (ZC) 1 and 2 and the locations of in situ measurements of ground temperatures $T_{\text {ground }}$ at different depths, as employed in Sect. 4.1. Two additional in situ measurements of ground temperatures at shallow depths are located approx. $0.5 \mathrm{~km} \mathrm{NE}$ and SW of the displayed scene. Coordinates are in UTM zone 27; note that ZERO-line continues further NE to the top of Aucellabjerg.

lustrated conceptually as a transect across typical landscape forms in the valley from hilltops to depressions. The top of the hills are windblown and exposed throughout the year with little or no accumulation of snow. From the hilltops towards the depressions there is an increase in soil water content from dry conditions (even arid conditions and salt accumulation at the soil surface) at the hilltops to wet conditions in the bottom of the depression. The dominant wind pattern during winter leaves large snow patches on the south-facing slopes ensuring high surface and soil water contents during a large part of the growing season.

Bay (1998) described and classified the plant communities in the central part of the Zackenberg valley and mapped their distribution. The vegetation zones range from fens in the depressions to fell-fields and boulder areas towards the hill tops. East of the river Zackenbergelven the lowland is dominated by Cassiope tetragona heaths mixed with Salix arctica snow beds, grasslands and fens; the latter occurring in the wet, low-lying depressions, often surrounded by grassland. On the transition from the lowland to the slopes of Aucellabjerg (50-100 $\mathrm{m}$ a.s.1.), the vegetation is dominated by grassland. Between 150 and $300 \mathrm{~m}$ a.s.l., open heaths of mountain avens, Dryas sp., dominate and gradually the vegetation becomes more open with increasing altitude towards the fellfields with a sparse plant cover of Salix arctica and Dryas sp. Grassland, rich in vascular plant species and mosses, occurs along the wet stripes from the snow patches in the highland (250-600 $\mathrm{m}$ a.s.1.).
For monitoring purposes, an $8 \mathrm{~km}$ transect cutting across the main ecological zones of the Zackenberg valley from sea level to $1040 \mathrm{~m}$ a.s.l. at the summit of Aucellabjerg has been established, which is considered representative of the Zackenberg valley (Fredskild and Mogensen, 1997; Meltofte et al., 2008). Along this so-called ZERO ("Zackenberg ecological research operations") line (Fig. 1), changes in species composition and distribution of plant communities are investigated regularly. In this study, we focus on lower $4 \mathrm{~km}$ of ZERO-line from the coast to an elevation of $200 \mathrm{~m}$ a.s.l., which is characterized by a strong variability as exemplified by the normalized difference vegetation index (NDVI) values (Fig. 1).

\section{Modeling tools}

In order to determine the spatial variability of ground temperatures in the Zackenberg valley, simulations from 1960 to 2100 are performed for grid cells of $10 \mathrm{~m}$ resolution for the lower $4 \mathrm{~km}$ of ZERO-line (in total 437 grid cells). In addition, the $100 \mathrm{~m} \times 100 \mathrm{~m}$ large CALM sites ZeroCalm 1 and 2 are simulated (Fig. 1, in total 200 grid cells). To compile forcing data sets at such high resolution, a multi-step downscaling procedure is employed which is schematically depicted in Fig. 2. It is designed to account for the spatial variability of snow depths, differences in summer surface temperature (due to, e.g., different evapotranspiration rates caused by surface soil moisture and land cover) and spatially variable ground 


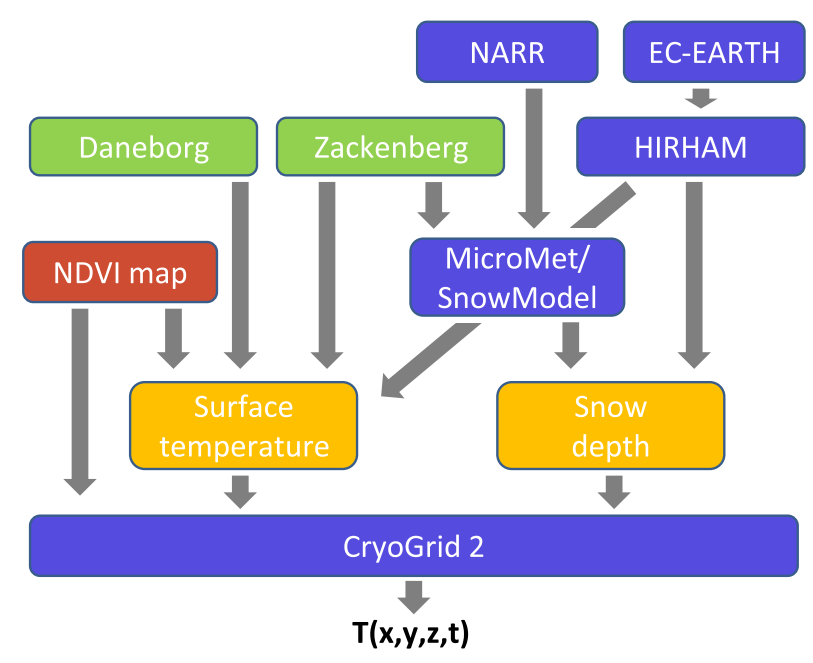

Figure 2. Schematic workflow of the modeling scheme depicting field data (green), remote sensing data (red), models (blue) and the principal forcing data (yellow) for the thermal model CryoGrid 2, delivering spatially resolved fields of ground temperatures. See text.

thermal properties and water/ice contents. Differences in insolation due to exposition and aspect are not accounted for, which is acceptable for the gentle topography (average slope $2.8^{\circ}$ ) in the modeled part of ZERO-line. The different parts of the scheme and their interplay are described as follows.

\subsection{The permafrost model CryoGrid 2}

CryoGrid 2 is a one-dimensional, physically based thermal subsurface model driven by time series of near-surface air temperature and snow depth and has been recently employed to assess the evolution of permafrost extent and temperatures in southern Norway (Westermann et al., 2013). The physical basis and operational details of CryoGrid 2 are documented in Westermann et al. (2013), and only a brief overview over the model properties is given here. CryoGrid 2 numerically solves Fourier's law of conductive heat transfer in the ground to determine the evolution of ground temperature $T[\mathrm{~K}]$ over time $t$,

$c_{\mathrm{eff}}(z, T) \frac{\partial T}{\partial t}-\frac{\partial}{\partial z}\left(k(z, T) \frac{\partial T}{\partial z}\right)=0$,

with the thermal conductivity $k\left[\mathrm{~W} \mathrm{~m}^{-1} \mathrm{~K}^{-1}\right]$ being a function of the volumetric fractions and thermal conductivities of the constituents water, ice, air, mineral and organic (Westermann et al., 2013) following the formulation of Cosenza et al. (2003). For the thermal conductivity of the mineral fraction of the soil, we assume $3.0 \mathrm{~W} \mathrm{~m}^{-1} \mathrm{~K}^{-1}$, which is a typical value for sedimentary and metamorphic rock with low quartz content (Clauser and Huenges, 1995), as dominant in most parts of the Zackenberg valley (Koch and Haller, 1965). For the organic soil fraction, the standard value of
$0.25 \mathrm{~W} \mathrm{~m}^{-1} \mathrm{~K}^{-1}$ (e.g., Côté and Konrad, 2005) for peat is employed.

The latent heat from freezing soil water or melting ice is accounted for in terms of an effective heat capacity $c_{\text {eff }}$ $\left[\mathrm{J} \mathrm{m}^{-3} \mathrm{~K}^{-1}\right]$, which increases strongly in the temperature range in which latent heat effects occur. This curve is determined by the soil freezing characteristic, i.e., the function linking the soil water content to temperature, which is related to the hydraulic properties of the soil in CryoGrid 2 (Dall'Amico et al., 2011) for three soil classes: sand, silt and clay. To account for the buildup and disappearance of the snow cover, the position of the upper boundary is allowed to change dynamically by adding or removing grid cells. Movement of soil water is not accounted for so that the sum of the soil water and ice contents are constant in CryoGrid 2. For spatially distributed modeling, the target domain is decomposed in independent grid cells, each featuring a set of model parameters.

\subsubsection{Model initialization}

The initial temperature profile for each grid cell is obtained by a multi-step initialization procedure which allows us to approximate steady-state conditions in equilibrium with the climate forcing for the first model decade (September 1958August 1968) in a computationally efficient way. The method which is described in more detail in Westermann et al. (2013) accounts for the insulating effect of the seasonal snow cover as well as the thermal offset (Osterkamp and Romanovsky, 1999).

\subsubsection{Driving data sets}

As driving data sets for CryoGrid 2 we use gridded data sets of daily average air temperature and snow depth obtained from a downscaling scheme and a snow redistribution model (Sects. 3.3, 3.4). To account for differences in surface soil moisture between grid cells, which give rise to spatially different surface temperatures, we employ the empirical concept of $n$ factors which relate average air temperature $T_{\text {air }}$ to surface temperature $T_{\mathrm{s}}$ by $T_{\mathrm{s}}=n_{\mathrm{t}} T_{\text {air }}$ :

$T_{\mathrm{S}}= \begin{cases}T_{\text {air }} & \text { for } T_{\text {air }} \leq 0^{\circ} \mathrm{C} \\ n_{\mathrm{t}} T_{\text {air }} & \text { for } T_{\text {air }}>0^{\circ} \mathrm{C} .\end{cases}$

This rough treatment of summer surface temperatures (which has been applied in previous modeling studies, e.g., Hipp et al., 2012) is focused on seasonal averages and can not reproduce surface temperatures on shorter timescales, e.g., the daily cycle. As a result, a comparison of temperatures in upper soil layers is less meaningful than for deeper layers, which are only influenced by seasonal or even multi-annual average temperatures. However, the $n$ factor-based approach precludes the need to compute the surface energy balance and allows employing measured historic time series of air temperatures (such as the one from Daneborg, Sect. 3.4) for ground thermal modeling. 


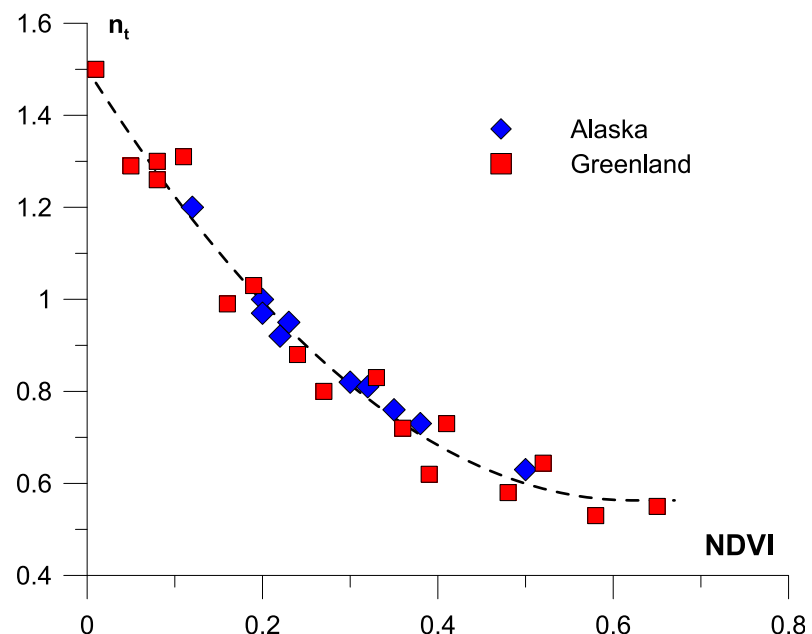

Figure 3. Summer $n_{t}$ factor vs. NDVI based on in situ measurements from Zackenberg and Kobbefjord in Greenland and from northern Alaska (Klene et al., 2001; Walker et al., 2003). The black line represents the fit following Eq. (3), $R^{2}=0.97$.

The summertime $n$ factor $n_{t}$ is computed according to the NDVI of each grid cell (at the maximum of the growing season) using

$n_{t}=2.42 \mathrm{NDVI}^{2}-3.01 \mathrm{NDVI}+1.54$.

The relationship is compiled with $n_{t}$ as the ratio of degreeday sums at the soil surface to those in the air over the summer season at both Zackenberg $\left(74.5^{\circ} \mathrm{N}\right)$ and Kobbefjord $\left(65.6^{\circ} \mathrm{N}\right)$, close to Nuuk in western Greenland. Figure 3 also shows a strong correlation between $n_{t}$ values (Klene et al., 2001) and NDVI values (Walker et al., 2003) from the Kuparuk River basin, Alaska, USA, with an $R^{2}$ value of 0.97 for the combined data set. Summer $n_{t}$ factors above 1 indicate that the soil-surface temperatures are warmer than air temperatures; this mostly occurs on nearly barren mineral soils. The minimum $n_{t}$ values of approx. 0.65 are found in moist fen areas, indicating a strong cooling effect during the summer on the mineral soils of these sites.

For each $10 \mathrm{~m}$ model grid cell, an NDVI value was determined from a $2.5 \mathrm{~m}$ multi-spectral Quickbird 2 image of the Zackenberg area acquired around noon local time on 7 July 2011 (Fig. 1). Whereas the acquisition date is close to the annual maximum NDVI values, it represents a single point in the time, and there is strong seasonal and interannual variability in plant growth and consequent evolution of NDVI values (Tamstorf et al., 2007). While this error source is hard to quantify, the general agreement in the coverage of the different vegetation classes (see next section) with field observations suggests that the satellite image is an adequate basis to capture the pattern of surface soil moisture and summer surface temperatures along ZERO-line.

\subsubsection{Ground properties}

Based on a NDVI-classification, six ecosystems were identified in Zackenberg valley (Bay, 1998; Tamstorf et al., 2007; Ellebjerg et al., 2008). Areas with NVDI $<0.2$ are dominated by fell-field with a sparse vegetation. In the high mountains such areas are found on solifluction soils, patterned ground and rocky ravines. Dryas heath dominates areas with NDVI between 0.2 and 0.3. Fell-field and Dryas heath are both situated at exposed plateaus, where snow often blows off during the winter months causing thinner snow cover. Here, plant species experience an early snowmelt and hence an early start of the growing season. Cassiope heath (NDVI between 0.3 and 0.4 ) depends on a protective snow cover during winter and occurs mainly in the lowland on gentle slopes facing south and leeward from the northerly winds which dominate the winter period (Hansen et al., 2008). Salix snow beds feature NDVI values between 0.4 and 0.5 . This ecosystem, which is unique to eastern Greenland, occurs mostly on sloping terrain, often below the Cassiope heath belt on the slopes, where the snow cover is long lasting so that the soil moisture in the Salix snow-bed areas are higher. In the wetland areas with NDVI higher than 0.5, grassland and fen areas are distinguished. Grassland occurs mostly on slightly sloping terrain with an adequate supply of water early in the season, while the soil water regime can change from wet to moist later in the season. The fen areas occur on flat terrain in the lowland, where the soil is permanently water-saturated throughout the growing season. In August 2013, a classification of ecosystem classes according to the dominating plant species and qualitative surface moisture conditions was conducted along the modeled part of ZERO-line at spatial resolution of $10 \mathrm{~m}$, which resulted in 5\% fell, $20 \%$ Dryas, $35 \%$ Cassiope, $15 \%$ Salix snow bed and $25 \%$ wetland (fen and grassland areas were not distinguished).

Using satellite-derived NDVI values (see previous section), these ecosystem fractions could be well reproduced for fell (9\%), Dryas (22\%) and Cassiope (39\%), while a strong discrepancy was encountered for the Salix and wetland classes. Therefore, Salix snow bed was merged with wetland, yielding a wetland fraction of $30 \%$. The "true" Salix class is hereby split between Cassiope and wetland, which is reflected in the strong concentration of grid cells with NDVI values around 0.4. This suggests a significant overlap of the NDVI values from the different classes in this region for the particular satellite acquisition date, so that the classes can not be separated by their NDVI value. While the NDVI-derived ecosystem classification constitutes a potentially important source of uncertainty in the modeling chain, it provides the possibility to use satellite images and thus apply the classification procedure for larger regions, e.g., the entire Zackenberg valley, at high spatial resolutions, which can hardly be achieved by manual mapping.

For the remaining four classes fell, Dryas, Cassiope and wetland, typical soil stratigraphies were assigned based on 
Table 1. Sediment stratigraphies in CryoGrid 2 with volumetric fractions of the soil constituents and soil type for each layer given.

\begin{tabular}{llllll}
\hline Depth (m) & Water/ice & Mineral & Organic & Air & Type \\
\hline Fell & & & & & \\
\hline $0-3$ & 0.05 & 0.6 & 0.0 & 0.35 & sand \\
$3-10$ & 0.4 & 0.6 & 0.0 & 0.0 & sand \\
$>10$ & 0.03 & 0.97 & 0.0 & 0.0 & sand \\
Dryas & & & & & \\
\hline $0-1$ & 0.15 & 0.55 & 0.0 & 0.3 & sand \\
$1-10$ & 0.4 & 0.6 & 0.0 & 0.0 & sand \\
$>10$ & 0.03 & 0.97 & 0.0 & 0.0 & sand \\
Cassiope heath & & & & \\
\hline $0-0.8$ & 0.25 & 0.55 & 0.0 & 0.2 & sand \\
$0.8-10$ & 0.4 & 0.6 & 0.0 & 0.0 & sand \\
$>10$ & 0.03 & 0.97 & 0.0 & 0.0 & sand \\
Wetland & & & & & \\
\hline $0-0.6$ & 0.5 & 0.45 & 0.05 & 0.0 & silt \\
$0.6-10$ & 0.4 & 0.6 & 0.0 & 0.0 & silt \\
$>10$ & 0.03 & 0.97 & 0.0 & 0.0 & sand \\
\hline
\end{tabular}

and guided by in situ measurements in soil samples (Table 1). The stratigraphies are designed to represent the characteristics of the different ecosystem classes at least in a semi-quantitative way: from fell to wetland, the water contents in the active layer increase from dry to saturated conditions, while the soil texture changes from coarse to more fine-grained in conjunction with increasing porosity. The absolute values are derived from soil samples taken at depths between 0 and $0.5 \mathrm{~m}$ in the different classes mainly in July 2006 and 2007. For wetland and Cassiope, the average of all values yielded volumetric water contents of 0.52 and 0.28 , respectively. Furthermore, transient simulations of the onedimensional water balance and ground thermal regime with the COUP model suggest average soil water contents between 0.2 and 0.3 for the active layer at a Cassiope site (Hollesen et al., 2011). For the Dryas and fell classes, large changes in soil moisture were encountered after rain falls which made the values strongly dependent on the timing of the sampling. The volumetric organic material contents are low in all classes (5\% or less) and have negligible influence on the thermal properties of the soil. Following measurements of soil cores to $2 \mathrm{~m}$ depth (Elberling et al., 2010), saturated conditions are assumed below the current active layer for all classes (Table 1), except for fell for which no in situ data are available and saturated conditions are assumed below a depth of $3 \mathrm{~m}$. Furthermore, bedrock is assumed below $10 \mathrm{~m}$, which is a pure estimate but has limited influence on the outcome of the simulations.

Snow properties: in CryoGrid 2, constant thermal properties in space and time are assumed for the snow cover (see Westermann et al., 2013, for details). Following in situ measurements, a snow density of $300 \mathrm{~kg} \mathrm{~m}^{-3}$ is employed, which results in a volumetric heat capacity of $c_{\text {snow }}=$ $0.65 \mathrm{MJ} \mathrm{m}^{-3} \mathrm{~K}^{-1}$. In the absence of in situ measurements of the thermal conductivity of the snow cover, we use the empirical relationship between density and thermal conductivity from Yen (1981), which is also employed in the detailed snowpack scheme CROCUS (Vionnet et al., 2012). The resulting value is $k_{\text {snow }}=0.25 \mathrm{~W} \mathrm{~m}^{-1} \mathrm{~K}^{-1}$, slightly lower than those employed in CryoGrid 2 simulations for the mountain environments of southern Norway where average winter temperatures are higher than in Zackenberg, but predominantly wind-packed snow is encountered as well.

\subsection{Future climate scenario with HIRHAM}

There are several types of uncertainties related to climate projections. Apart from "external" uncertainties such as the future evolution of greenhouse gas emissions, there are also "internal" uncertainties related to different parameterizations of subgrid-scale processes. Even though it is possible to model the distribution of permafrost on rather coarse scales (Stendel and Christensen, 2002), it is desirable to use a GCM with as high resolution as possible, which serves as the basis for downscaling to the target grid of a RCM driven with these fields.

The climate model EC-EARTH (v2.3) is such a GCM. It consists of the Integrated Forecast System (IFS) developed at the European Centre for Medium-Range Weather Forecasts (ECMWF) as the atmospheric component, the Nucleus for European Modelling of the Ocean (NEMO) version 2 as the ocean component and the Louvain-la-Neuve sea ice model (LIM2). These components are coupled using the OASIS3 coupler (Hazeleger et al., 2010, 2012). The IFS in the current EC-EARTH model is based on ECMWF cycle 31r1 with some improvements from later cycles implemented, including a new convection scheme and a new land surface scheme (H-TESSEL) as well as a new snow scheme (Hazeleger et al., 2012). The atmospheric part of EC-EARTH is configured with a horizontal spectral truncation of T159, which is approximately $125 \mathrm{~km} \times 125 \mathrm{~km}$ in latitude and longitude. The vertical resolution is 62 layers. The ocean and sea ice components have 42 vertical layers and a roughly $1^{\circ}$ horizontal resolution with refinement to $1 / 3^{\circ}$ around the equator. ECEarth is one of the models of CMIP5 (Coupled Model Intercomparison Project) and has been used for the experiments for the IPCC AR5 report.

To resolve the topography of Greenland adequately, a horizontal resolution of $5 \mathrm{~km}$ or finer is required (Lucas-Picher et al., 2012). The output of EC-Earth is therefore downscaled to the RCM grid. The RCM used here is HIRHAM5 in its newest version, which includes calculation of the surface mass balance of the Greenland Ice Sheet. A surface snow scheme has been implemented over glaciers. The model setup is described in Rae et al. (2012) except that the resolution here is $0.05^{\circ}(5.5 \mathrm{~km})$ instead of $0.25^{\circ}(27 \mathrm{~km})$, as in 
Langen et al. (2015). EC-Earth has a slight cold bias, probably caused by albedo values that are too high, so that the estimates of surface mass balance under climate change conditions are slightly higher than observed.

EC-Earth and HIRHAM have been run for three time slices, namely 1991-2010, 2031-2050 and 2081-2100. The scenario used was RCP 4.5 (Thomson et al., 2011; Clarke et al., 2007; Smith and Wigley, 2006; Wise et al., 2009), which gives an additional radiative forcing in 2100 with respect to preindustrial values of $4.5 \mathrm{~W} \mathrm{~m}^{-2}$. In this rather conservative scenario, $\mathrm{CO}_{2}$ emissions peak around 2040 and decline thereafter, resulting in a $\mathrm{CO}_{2}$ concentration of $550 \mathrm{ppm}$ in 2100 , which is just below a doubling with respect to preindustrial values.

\subsection{Modeling snow distribution by MicroMet/SnowModel}

SnowModel is a spatially distributed snow-evolution modeling system (Liston and Elder, 2006a) which was applied in the Zackenberg study area $(14 \mathrm{~km} \times 12 \mathrm{~km})$ to describe the snow distribution through a 7-year period covering August 2003 to September 2010. SnowModel consists of three interconnected submodels: Enbal, SnowPack and SnowTran-3D. Enbal calculates surface energy exchanges and snowmelt (Liston, 1995, 1999), SnowPack models the evolution of the snow depth and snow-water equivalent in time and space (Liston and Hall, 1995; Liston and Mernild, 2012) and SnowTran-3D generates the transport of blowing snow (Liston and Sturm, 1998; Liston et al., 2007). SnowModel was coupled with a high-resolution atmospheric model, MicroMet (Liston and Elder, 2006b), which spatially distributed the micrometeorological input parameters over the simulation domain. MicroMet requires meteorological station and/or atmospheric (re)analysis inputs of air temperature, relative humidity, precipitation, wind speed, and wind direction. Furthermore, available observed incoming shortwave and long-wave radiation were included. All meteorological parameters except precipitation were measured by five automatic weather stations distributed in the valley and on mountains contained within the simulation domain (Table 2).

Because of missing data and uncertainties associated with in situ winter precipitation measurements, MicroMet precipitation inputs were provided by the North American Regional Reanalysis (NARR) (Mesinger et al., 2006). These NARR precipitation fluxes were adjusted using the SnowAssim (Liston and Hiemstra, 2008) data assimilation scheme under the constraint that modeled snow-water-equivalent depth matched observed pre-melt snow depth and snow density at locations where those observations were made. Additionally, a digital elevation model (DEM) and a land-cover map were required for the MicroMet/SnowModel simulations. These distributions were provided over the simulation domain at a $10 \mathrm{~m} \times 10 \mathrm{~m}$ spatial resolution. The DEM was based on an August 2000 aerial survey, and the landcover map was based on the Elberling et al. (2008) vegetation classification (see Sect. 3.1 - Ground properties). From the land-cover map, a snow-holding depth (shd) was assigned to each class, i.e., the depth to which the vegetation is able to hold the snow and prevent snow transport by wind (snow exceeding this depth is available for wind redistribution). This snow-holding depth was set according to vegetation/canopy height but also included the micro-topographic relief within a $10 \mathrm{~m} \times 10 \mathrm{~m}$ grid cell. The classes "fell", "Dryas", "Cassiope heath" and "Wetland" were assigned a shd of 0.01 , $0.05,0.20$ and $0.20 \mathrm{~m}$, respectively. The modeled mean snow depth along ZERO-line was on the order of tens of $\mathrm{cm}$, while the modeled maximum snow depth was several meters in the winters 2003/2004-2009/2010. Both the annual mean and maximum snow depth varied by a factor 1.5 from year to year. The modeled mean snow depth exceeded the snowholding depth in all vegetation classes, so that the parameter shd had minor influence on snow distributions and winter accumulation. The modeled snow depths were validated against automated and manual measurements conducted at the ZeroCalm sites close to the ZERO-line. Automated measurements of snow depth acquired at a point near ZeroCalm 1 were compared to the model results at the closest grid cell. Linear regression analyses showed that the modeled snow depth represented $77-97 \%$ of the variability in the observed snow depth in 5 of the 7 hydrological years and approximately $47 \%$ in 2 years (2004/2005 and 2008/2009). However, MicroMet/SnowModel results showed an earlier snowfall than in reality, most likely due to the monthly applied lapse rates which caused snowfall instead of rain in the simulations. As a result, the modeled snow depths featured a positive bias of on average of $0.16 \mathrm{~m}$ (2005-2010) compared to the observed snow depths. The performance of MicroMet/SnowModel in reproducing the spatial distribution of snow depths was investigated by comparing to snow depths measured manually at one date between mid-May and midJune for the years 2005-2008 and 2010 at $>150$ sites within ZeroCalm 1 and 2. Figure 4a displays the comparison of the cumulative distributions of all measurements to the modeled snow depths for the corresponding dates using all grid cells within ZeroCalm 1 and 2 . The results suggest that $\mathrm{Mi}$ croMet/SnowModel can generally reproduce the range and distribution of snow depths to a satisfactory extent, but some deviations occur in particular for low and high snow depths. Note that the measurements were conducted at the end of the snow season and in some years are heavily influenced by ongoing snowmelt.

In addition, the timing of the snowmelt was compared to in situ measurements similar as in Pedersen et al. (2015). At the automated station near ZeroCalm 1 (see above), SnowModel/MicroMet represented the timing of snowmelt with on average \pm 4 days, while the maximum deviation was 8 days (Fig. 4b). For ZERO-line, the modeled melt-out dates were validated by comparing them to orthorectified images 
Table 2. The five climate stations in Zackenberg used to provide MicroMet/SnowModel meteorological inputs.

\begin{tabular}{lrrrr}
\hline Station & $\begin{array}{r}\text { Altitude } \\
\text { (ma.s.1.) }\end{array}$ & Time series & $\begin{array}{r}\text { UTM } \\
\text { Easting }\end{array}$ & $\begin{array}{r}\text { UTM } \\
\text { Northing }\end{array}$ \\
\hline Main climate station & 38 & 1996 -present & 513382 & 8264743 \\
M2 & 17 & 2003 -present & 513058 & 8264019 \\
M3 (Aucella) & 410 & 2003 -present & 516126 & 8268250 \\
M6 (Dome) & 1283 & $2006-2012$ & 507453 & 8269905 \\
M7 (Stor Sødal) & 145 & 2008 -present & 496815 & 8269905 \\
\hline
\end{tabular}
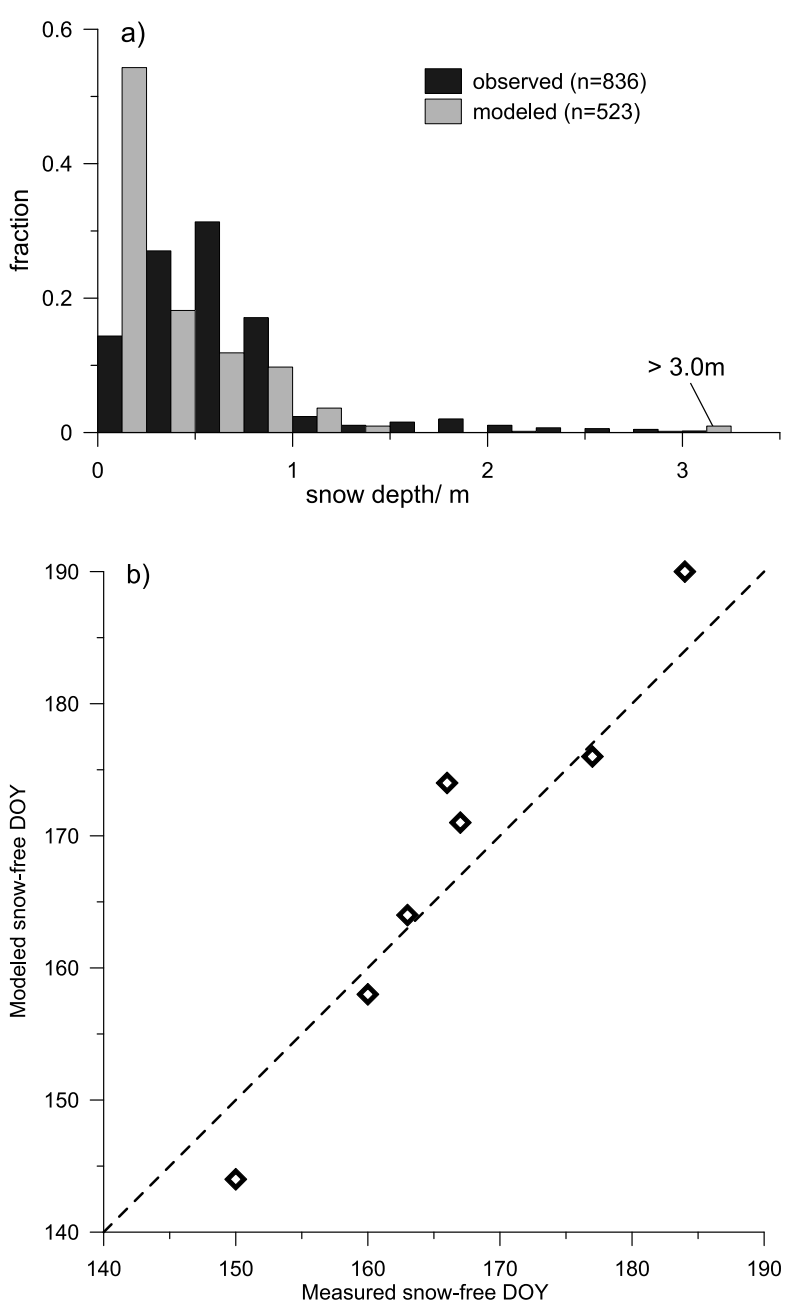

Figure 4. (a) Cumulative histogram of measured and modeled snow depths at ZeroCalm 1 and 2 for 20 May 2005, 7 June 2006, 26 May 2007, 2 June 2008 and 16 May 2010. The measurements were taken along transects across ZeroCalm 1 and 2 and do not represent the locations of the model grid cells. The five modeled grid cells with snow depths $>3.0 \mathrm{~m}$ feature snow depths of $3.2 \mathrm{~m}(2 \times), 4.0,4.5$ and $5.4 \mathrm{~m}$. (b) Modeled vs. measured day of year (DOY) of the termination of snowmelt at the automated snow depth monitoring station next to ZeroCalm 1 for the years 2004-2009. The dashed line represents the 1:1 line. (resolution $5 \mathrm{~m}$ ) taken by an automatic camera system located on a mountain slope at $400 \mathrm{~m}$ a.s.l. overlooking ZEROline (Hinkler et al., 2002) for the years 2006 to 2009. From grayscale images, the presence or absence of snow was determined using a simple threshold filter, which was adapted for each year. In case of missing images due to clouds in front of the camera, the date of the snowmelt was set to the midpoint between the last snow-covered and the first snow-free date. The results confirm the results from the comparison to point observations: in 2006, the deviation of the melt-out dates between measurements and SnowModel/MicroMet results was $0.0 \pm 8.6$ days, $-1.8 \pm 5.6$ days in $2007,0.7 \pm 8.2$ days in 2008 and $5.4 \pm 6.0$ days in 2009. The melt-out date is, therefore, represented within 1 week for most grid cells, but larger deviations can occur for a number of grid cells. Note that cloudy periods with no images of up to 4 days lead to an uncertainty of several days in the determination of the snowmelt date for some years and pixels. Furthermore, Hinkler et al. (2002) suggest an absolute referencing error of about $10 \mathrm{~m}$ for each pixel, which also contributes to a reduced match between images and model results.

\subsection{Downscaling scheme from GCM to plot scale}

To run simulations of permafrost temperatures from 1958 to 2100, a continuous record of the driving data air temperature and snow depth was compiled from various sources. The method assumes that trends in air temperature and precipitation measured at one point or modeled by a medium-scale atmospheric scheme are representative for the trends along ZERO-Line.

- For the period from 2003 to 2010, a continuous record of forcing data is derived for all $10 \mathrm{~m}$ grid cells from the output of MicroMet/SnowModel (Sect. 3.3). This data set constitutes the basis upon which statistical downscaling of point measurements and RCM output (Sect. 3.2) is performed for the remaining time periods.

- To synthesize past air temperature, we employ the longterm air temperature record from Daneborg $\left(74^{\circ} 18^{\prime} \mathrm{N}\right.$, $20^{\circ} 13^{\prime} \mathrm{E}$ ), located about $25 \mathrm{~km}$ west of Zackenberg, for which an hourly record is available for the periods 1958-1975 and 1979-2011. For these periods, daily means were calculated for each year. The gap was filled 
using random years selected from the 5 years before the gap for the first half and the first 5 years after the gap for its second half. In addition, a monthly trend was superimposed on the randomly selected data, obtained by linear interpolation between the monthly averages from 5 years before and 5 years after the gap. With this procedure, both a smooth transition between the time slices and a simulated natural variability was achieved.

- For present-day and future air temperatures, the nearsurface air temperature from the HIRHAM5 $5 \mathrm{~km}$ grid cell closest to the study area, which are available for three time slices, 1991-2010, 2031-2050 and 20812100. The gaps in between the time slices were filled similar to the gap in the Daneborg record.

- To account for differences in the climate setting between the study area and Daneborg/the HIRHAM grid cell, we calculate the offset of the average air temperatures between the Daneborg/HIRHAM records and the MicroMet/SnowModel output for the period 20032010 , for which all time series are available simultaneously. A specific offset is calculated for each grid cell and for each month of the year, thus accounting for both the spatial gradients along Zero Line and the average seasonal differences between the two sites.

- For both the past Daneborg and the future HIRHAM time series, the difference to the monthly average of the 2003-2010 reference period (i.e., a monthly time series of offsets) was calculated. The final time series was synthesized by selecting air temperatures from MicroMet/SnowModel for random years from 2003 to 2010 and subtracting the spatial and temporal offsets for each grid cell and each month, respectively.

- Snow depths were obtained by a similar procedure. Since a past record was not available and neither snow depth nor winter snowfall modeled by HIRHAM showed a significant trend, the snow depth was taken from random years of the MicroMet/SnowModel period (the same year as used for air temperatures) during the buildup period. To model past and future snowmelt in climate conditions different from the 2003-2010 MicroMet/SnowModel period, a simple degree-day model linking melt rates to air temperature (e.g., Hock, 2003) was applied. We assumed a constant melt factor of $2.5 \mathrm{~mm}$ snow water equivalent per degree day for temperatures exceeding $-2{ }^{\circ} \mathrm{C}$. The numbers were obtained by fitting the snowmelt dates delivered by MicroMet/SnowModel for the $43710 \mathrm{~m}$ grid cells along ZERO-line for the years 2003-2010. The average bias in the snowmelt date of the degree-day melt model is 1.2 day compared to MicroMet/SnowModel. The ablation of the snow cover was subsequently calculated using the downscaled air temperatures for each day. For air temperatures colder than the MicroMet/SnowModel period, this yields a later snowmelt, while the snow melts earlier for warmer conditions.

\section{Model results}

\subsection{Comparison to field data}

To build confidence that the modeling is a satisfactory representation for the true ground thermal conditions, the model results are compared to available in situ data sets. These comprise in particular thaw depth measurements at ZeroCalm 1 and 2 since 1996, measurements of thaw depth along ZEROline in 2013 and measurements of ground temperatures conducted in the active layer and the permafrost between 1996 and 2014 at 17 sites.

\subsubsection{Active layer thickness}

The modeled and measured maximum thaw depths for 7 years for which MicroMet/SnowModel was run are shown in Fig. 5, with the areas selected for comparison equal to Elberling et al. (2013). Most importantly, CryoGrid 2 can capture the significant differences between the three sediment classes Dryas, Cassiope and wetland caused by different ground and surface properties. With a few exceptions, CryoGrid 2 can reproduce the measured thaw depth within the spatial variability in the validation areas (indicated by the error bars in Fig. 5), with the exception of the year 2006 which features stronger deviations from the measurements. The spatial variability within the target areas is significantly smaller in the model runs than in nature, most likely since the sediment classification assumes constant soil properties within each class, while the soil composition can vary significantly within a class in reality.

On 26 August 2013, thaw depths were measured manually along the modeled part of ZERO-line at intervals of $30-40 \mathrm{~m}$. Although MicroMet/SnowModel data were not employed in the modeling of this year, a comparison to modeled data is meaningful to assess the general range and distribution of thaw depths along ZERO-line. The measured and modeled distributions of thaw depths are displayed in Fig. 6. Although thaw depths deeper than $1.0 \mathrm{~m}$ could not be measured in the field, the comparison shows that the modeling can generally reproduce the range of thaw depths. Furthermore, the modeled and measured fractions of thaw depths larger than $1.0 \mathrm{~m}$ are approximately equal. All model grid cells with such large thaw depths belong to the class fell, which is an indication that the modeling procedure is adequate also for fell. For thaw depths between 0.4 and $0.7 \mathrm{~m}$, differences in the modeled fractions occur (Fig. 6). However, this can be explained by deviations between measured and modeled thaw depth on the order of 0.1 to $0.2 \mathrm{~m}$, which is in agreement with the comparison of Fig. 5. 

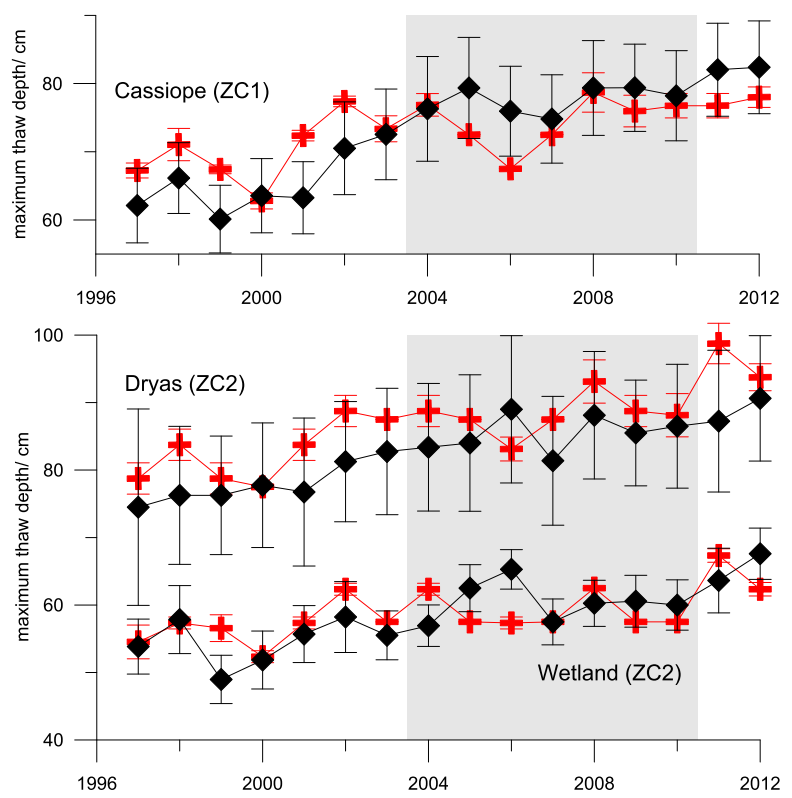

Figure 5. Modeled (red) and measured (black) maximum thaw depths for the classes Dryas, Cassiope and wetland in ZeroCalm (ZC) 1 and 2. The period for which MicroMet/SnowModel data are available is shaded gray. The error bars correspond to the standard deviation of the model grid cells and the in situ CALM measurements.

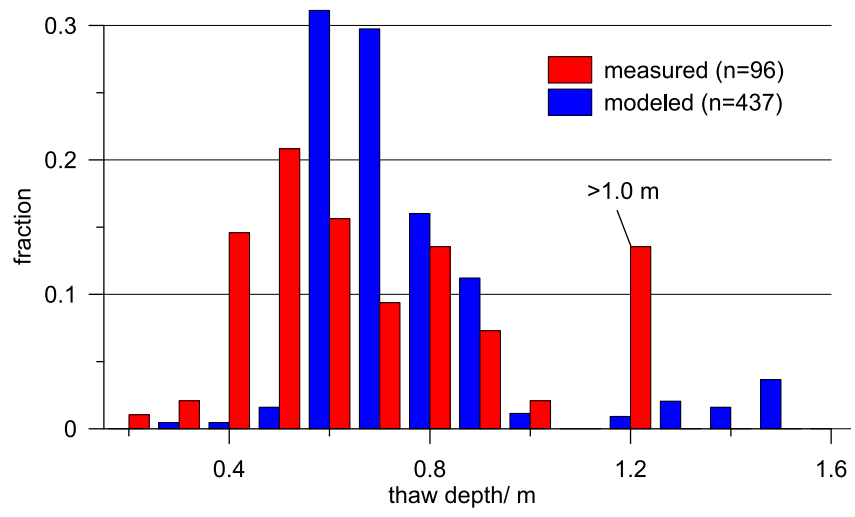

Figure 6. Distributions of measured and modeled thaw depths along the modeled part of ZERO-line on 26 August 2013. Due to the limited length of the active layer probe, thaw depths exceeding $1.0 \mathrm{~m}$ could not be determined exactly and are plotted as a single bin at $1.2 \mathrm{~m}$.

\subsubsection{Ground temperatures}

To assess the model performance for ground temperatures, measurements conducted in the vicinity of ZERO-line (Fig. 1) between 1996 and 2014 are employed. The comparison focuses on annual average near-surface ground temperatures (depths between 0.15 and $1.0 \mathrm{~m}$ ), for which in total 47 data points from 17 different sites are available (Fig. 7). The majority of the data points are contained within the range

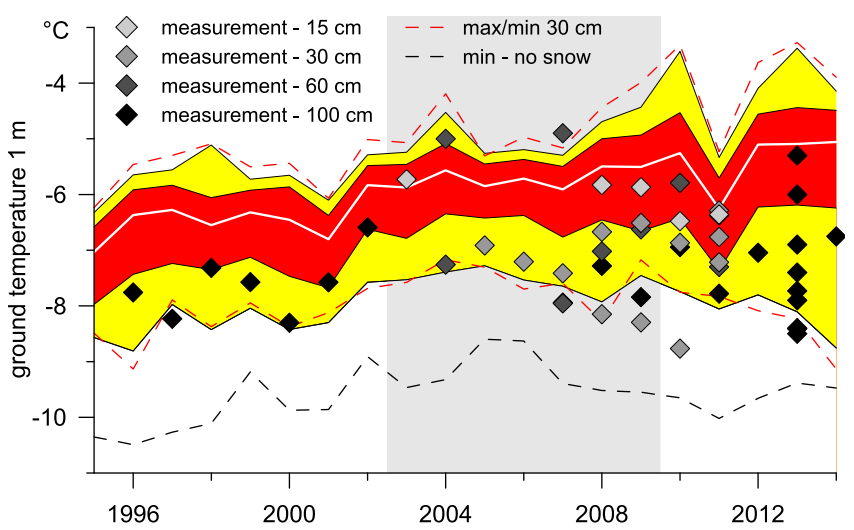

Figure 7. Evolution of annual average ground temperatures at $1 \mathrm{~m}$ depth along the modeled part of ZERO-line for the period with in situ data from various depths for comparison. The white line is the average of all grid cells; red are the 25 and $75 \%$ quartiles; yellow is minimum to maximum. In addition, minimum and maximum of the annual average ground temperatures at $0.3 \mathrm{~m}$ depth and the minimum of modeled temperatures with no snow cover (depth $1 \mathrm{~m}$ ) are shown. The measurements are annual averages for the respective depths. The period for which MicroMet/SnowModel data are available is shaded gray.

of modeled ground temperatures at $1.0 \mathrm{~m}$ depth, but small deviations of up to $0.5^{\circ} \mathrm{C}$ are common, both in negative and positive directions. Two data points feature larger deviations, with annual average temperatures about $1{ }^{\circ} \mathrm{C}$ colder than the minimum of the modeled temperatures along ZEROline in these years. As evident from the minimum and maximum modeled ground temperatures at $0.3 \mathrm{~m}$ depth displayed in Fig. 7, these deviations can in general not be explained by the fact that some of the measurements are from depths shallower than $1 \mathrm{~m}$. A possible explanation is the occurrence of spots with shallower snow depths than delivered by MicroMet/SnowModel, in particular at spatial scales of less than $10 \mathrm{~m}$. In addition, a too early onset of the snow cover, as found for the MicroMet/SnowModel grid cell at the automated snow depth station near ZeroCalm 1 (Sect. 3.3), could cause a warm bias of modeled ground temperatures. This is corroborated by model simulations assuming 0 snow depth throughout the entire model period, which is still significantly colder than the coldest measured annual average ground temperature (Fig. 7). Note that snow depth measurements at the sites of the ground temperature measurements, which could prove this hypothesis, do not exist and other reasons, such as a systematic bias of employed model parameters (e.g., the thermal conductivity of the snow) cannot be ruled out. Furthermore, it must be emphasized that the sites with ground temperature measurements do not represent a representative sample of the area, so that it is not possible to compare the distributions of ground temperatures (as for thaw depth, Fig. 6). Furthermore, most of the measurements are not directly located on ZERO-line, which is likely 


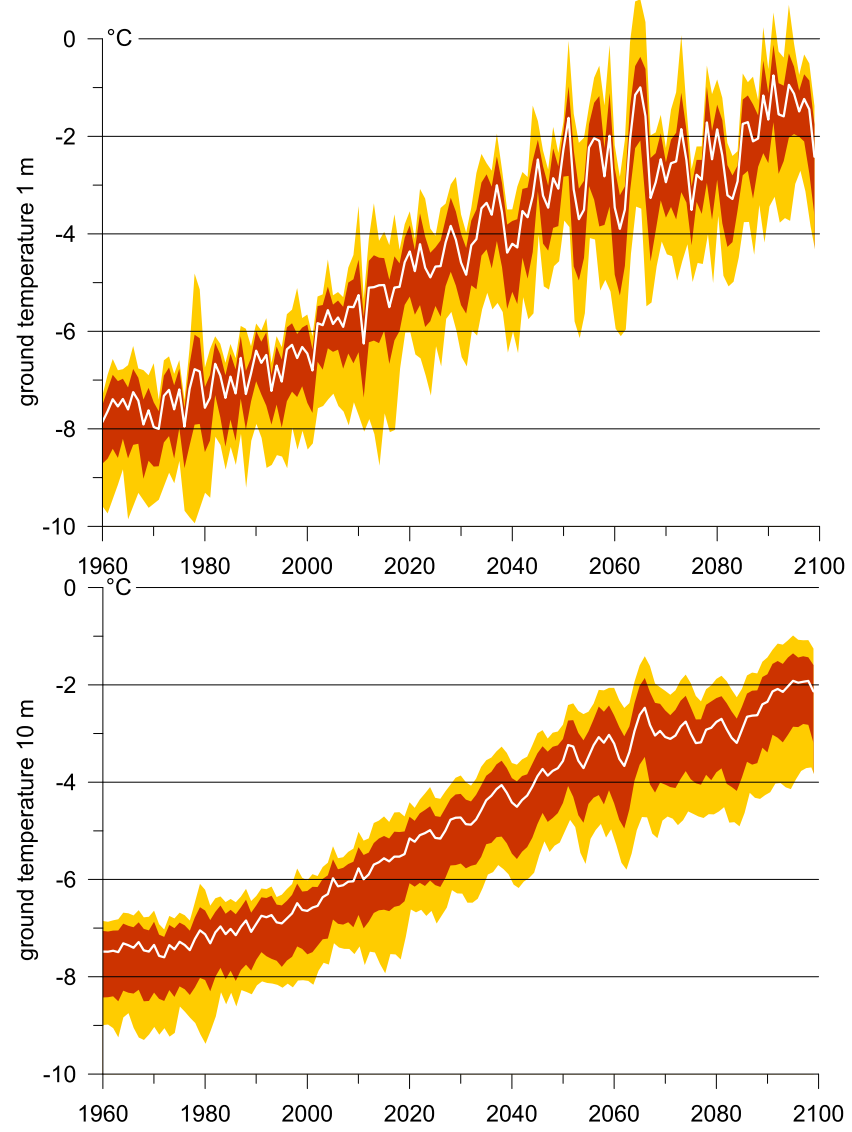

Figure 8. Evolution of annual average ground temperatures at $1 \mathrm{~m}$ (top) and $10 \mathrm{~m}$ (bottom) depth along the modeled part of ZERO-line until 2100. The white line is the average of all grid cells; red are the 25 and $75 \%$ quartiles; yellow is minimum to maximum.

to cause additional deviations between measurements and model results. Nevertheless, the comparison suggests that the modeling approach is able to capture the spatial variability of near-surface ground temperatures along and in the vicinity of ZERO-line.

In deeper layers, ground temperatures are influenced by the temperature forcing of an extended period prior to the measurement. Therefore, measurements in deep boreholes are especially well suited to check the long-term performance of a ground thermal model (in this case the model spin-up produced by statistical downscaling). In 2012, the two deep boreholes in the Zackenberg area featured temperatures at $10 \mathrm{~m}$ depth of $-5.2^{\circ} \mathrm{C}$ at a site with a snowdrift and $-6.7^{\circ} \mathrm{C}$ at the meteorological station with more regular snow conditions. These point measurements are well in the range of $10 \mathrm{~m}$ temperatures delivered by CryoGrid 2 along ZERO-line in $2012,(-6.0 \pm 0.6)^{\circ} \mathrm{C}$, and maximum and minimum temperatures of -5.1 and $-8.0^{\circ} \mathrm{C}$. The satisfactory agreement suggests that the statistical downscaling procedure (Sect. 3.4) employed to produce the forcing data for the model spin-up is adequate for the area.

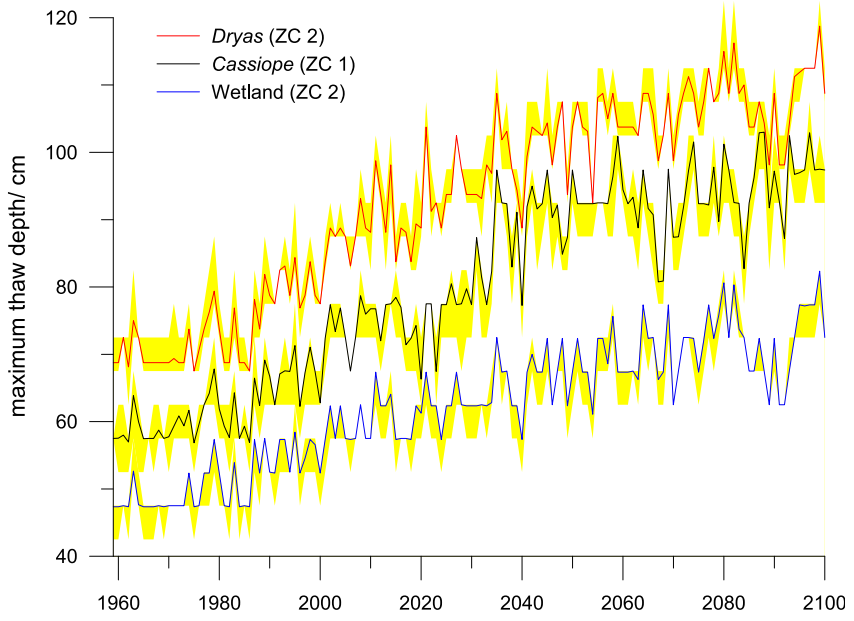

Figure 9. Evolution of annual maximum thaw depth until 2100 for the ecosystem classes Cassiope (ZeroCalm 1), Dryas and wetland (ZeroCalm 2). The yellow areas indicate the range of modeled maximum thaw depths.

\subsection{Evolution of active layer thickness and ground temperatures}

The modeled evolution of the temperature distribution at $1 \mathrm{~m}$ depth along ZERO-line is shown in Fig. 8. The modeled temperatures extend over a range of 2 to $5^{\circ} \mathrm{C}$ from minimum to maximum which is evidence of the significant spatial variability of the ground thermal regime in this landscape. In order to investigate the sources for this spatial variability, a sensitivity analysis was performed by running CryoGrid 2 for ZERO-line with a uniform ground stratigraphy and associated characteristic NDVI values (Sect. 3.1) for each of the four stratigraphic classes: fell, Dryas, Cassiope and wetland. This analysis suggests that snow depth has the largest effect on $1 \mathrm{~m}$ ground temperatures, with a variability 3-5 times larger than that caused by ground and surface properties. However, modeled maximum thaw depths are much more influenced by ground and surface properties than by snow depths, which only lead to differences on the order of 0.1 to $0.2 \mathrm{~m}$ compared to differences of more than $0.5 \mathrm{~m}$ for different stratigraphic classes/NDVI values. A statistically significant correlation between NDVI values (and thus stratigraphic classes) and snow depths modeled by SnowModel/MicroMet does not exist in the employed data set.

According to the climate change scenario of the future projections (Sect. 3.2), ground temperatures will warm by about $4{ }^{\circ} \mathrm{C}$ until 2100 , but permafrost will largely remain thermally sustainable along ZERO-line. However, the highresolution simulations suggest a few sites where the yearly average $1 \mathrm{~m}$ ground temperatures become positive in some years at the end of this century (Fig. 8). These sites are characterized by above-average snow depths in the long-term average, which suggests that talik formation may be initiated 
at sites with topographically induced snowdrifts. The future warming of air temperatures predicted by HIRHAM is not constant over the year, with the most pronounced warming of $0.4-0.6{ }^{\circ} \mathrm{C}$ per decade occurring in fall, winter and spring, while summer (June to August) temperatures increase by less than $0.2^{\circ} \mathrm{C}$ per decade. As a consequence, the annual maximum thaw depths increase only moderately until 2100 , from $0.8-1.0$ to $1.1-1.4 \mathrm{~m}$ for Dryas, from $0.65-0.85$ to $0.8-1.1 \mathrm{~m}$ for Cassiope and from $0.5-0.65$ to $0.6-0.8 \mathrm{~m}$ for the wetland class (Fig. 9). The climate sensitivity of thaw depths is different between the classes, with a stronger increase for the classes with dryer soils than for the wetlands. It is remarkable that the projected increase is only $0.1-0.2 \mathrm{~m}$ in the wetlands, which can be related to the high ice content in the frozen active layer and to relatively smaller increase in summer surface temperatures due to the low summer $n_{t}$ factors assigned to the wetland class (Fig. 3).

The biological activity in this high-Arctic ecosystem is strongly related to summer conditions. The simulations suggest a significant increase in average summer temperatures and thawing degree days (Fig. 10) within the effective root depth. The combination of deeper active layer (Fig. 9) and warmer near-surface (Fig. 10) summer conditions is an important control for plant growth. Water and nutrients (mainly nitrogen) are being released from the thawing permafrost, and the longer growing season and warmer top soil conditions allow plants to benefit from the additional nutrient and result in changes in the competition among plant species for light. This may lead to marked changes in vegetation over time, but this is beyond the scope of this study.

\section{Discussion}

\subsection{Scaling strategies from GCM to plot scale}

The presented simulations of ground temperatures and permafrost state variables are derived from a multi-step downscaling approach (Sect. 3.4) which bridges the coarse spatial resolution of a GCM (hundreds of $\mathrm{km}$ ) and the impact scale on the ground (set to $10 \mathrm{~m}$ for this study). As such, the scheme is technically capable of bridging 5 to 6 orders of magnitude in space. The two main driving environmental variables for the thermal model CryoGrid 2 are surface temperature and snow depth.

The snow depth is assumed to be controlled by wind drift of snow at the target scale of $10 \mathrm{~m}$ which is modeled by the snow redistribution scheme MicroMet/SnowModel. MicroMet/SnowModel is a deterministic scheme capable of predicting the snow depth for each model grid cell, thus reproducing the location of snow drifts and bare-blown spots. Such deterministic high-resolution modeling facilitates a better comparison and validation with ground observations but is restricted to small model domains for computational reasons. However, SnowModel also includes the ability to sim-

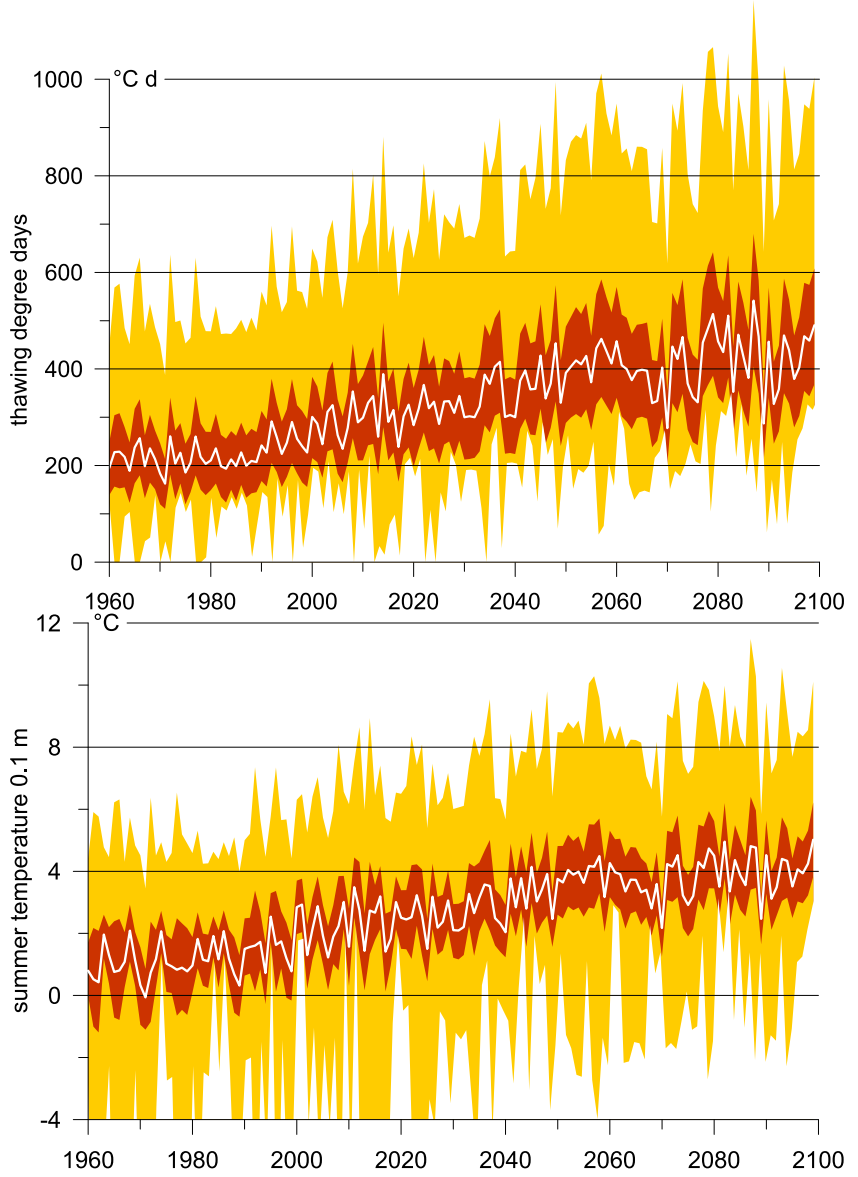

Figure 10. The distribution of thawing degree days (top) and average summer (June-August) temperatures (bottom) at $0.1 \mathrm{~m}$ depth along ZERO-line until 2100.

ulate snow distributions over large areas (e.g., the ice-free parts of Greenland, several $100000 \mathrm{~km}^{2}$ ) using, for example, subgrid snow distribution representations (e.g., Liston et al., 1999; Liston, 2004; Liston and Hiemstra, 2011). Gisnås et al. (2014) recently presented a statistical approach to account for the impact of the small-scale variability of snow depths on ground temperatures that is applicable on large spatial domains.

The surface temperature is derived from air temperature for which the regional gradients are based on the RCM at a scale of $5 \mathrm{~km}$. Within the target area along ZERO-line (a distance of $4 \mathrm{~km}$ ), variations in air temperature are generally small. Further downscaling to $10 \mathrm{~m}$ is accomplished by using a high-resolution NDVI satellite image and the NDVI vs. $n$ factor relationship (Sect. 3.1) which is used to convert air to surface temperatures during the snow-free season. By this scheme, a high-resolution data set of surface temperatures is generated from comparatively low-resolution air temperature data. More physically based approaches make use of the surface energy balance (SEB) to compute surface temperatures from air temperature, wind speed, humidity and 
incoming radiation (e.g., Zhang et al., 2013; Fiddes et al., 2015). In addition to accounting for more complex topography through spatially distributed fields of incoming radiation, the surface energy balance and thus the surface temperature can directly be connected to surface soil moisture and land cover/vegetation type, which circumvents the use of $n$ factors. Nonetheless, SEB models require additional driving data sets, in particular incoming radiation, which must be compiled, e.g., from large-scale atmospheric modeling (Fiddes and Gruber, 2014) and/or from sparse in situ measurements (Zhang et al., 2012). Due to the potential for serious biases in such driving data sets in remote locations (such as Zackenberg), it remains unclear whether the capacity of SEB models in reproducing the true surface temperature is superior to the simple empirical concept employed in this study.

\subsection{Model uncertainty}

The presented model results must be considered a first-order approximation of the future thermal state of the permafrost, which is subject to considerable uncertainty due to a variety of factors. Firstly, only one climate change scenario is considered, which does not account for the considerable spread in climate predictions. With permafrost approaching the thaw threshold at the end of this century for RCP 4.5 forcing, wide-spread permafrost degradation is e.g., likely for more aggressive climate change scenarios.

Secondly, the downscaling procedure from large-scale model data to high-resolution fields of temperature and snow depth is susceptible to uncertainties, since it assumes constant offsets between the two data sets based on the climate conditions of a 7-year reference period, which may not be justified for a 100-year period. This is particularly critical since the temperature regime in the study area is characterized by strong inversion settings during a large part of the year (Meltofte et al., 2008). A modification of such inversions could lead to a different climate susceptibility of the study area compared to the large-scale trend, which cannot be captured during the reference period. Furthermore, the future snow distribution patterns are based on random years from the 7-year reference period, implying that the patterns are unchanged in a warmer future climate and that the reference period allows a representative sample of the interannual variability within the rest of the century. It is not unlikely that both assumptions are violated at least to a certain degree. In addition, new processes not accounted for by the modeling scheme might become relevant in the course of climate warming, e.g., the occurrence of wintertime rain events, which can lead to significant additional ground warming (Westermann et al., 2011).

The CryoGrid 2 permafrost model assumes properties and relationships compiled and adjusted for the present state to be valid in the future. This concerns in particular the NDVIbased summer $n$-factor relationship employed to derive surface from air temperatures (Sect. 3.1), as well the thermal properties of the snow and the ground stratigraphy. As an example, the snow density and thermal conductivity are likely to increase in a warmer climate, which would decrease the insulation of the winter snow cover and thus lead to colder temperatures, as suggested by the model. A sensitivity study for a transient thermal model similar to CryoGrid 2 in Siberia showed that the thermal properties of the snow cover are the critical source of uncertainty for successfully reproducing ground temperatures (Langer et al., 2013). A similar result was found in a sensitivity study with GEOtop (Endrizzi et al., 2014) for a site in the European Alps for which the assumed snow conditions crucially influenced the uncertainties of modeled ground temperatures (Gubler et al., 2013). Most likely, these findings are also applicable to this study and the representation of the snow cover (including snow water equivalent, density and thermal conductivity) deserves increased attention in future modeling approaches. However, the ground thermal properties related to the ground stratigraphy proved to be the crucial source of uncertainty regarding modeled thaw depths (Langer et al., 2013). In this study, constant soil water and ice contents are assumed in our modeling, thus neglecting both seasonal and long-term changes in the water cycle. However, at least for the Cassiope class, our results for the future increase in maximum thaw depth are in good agreement with the study of Hollesen et al. (2011) who used the coupled heat and water transfer model COUP (Jansson and Karlberg, 2004) to simulate the ground thermal and moisture regimes in this century. While a coupled energy and water cycle is implemented in a number of modeling schemes, such as GEOtop (Endrizzi et al., 2014) or Surfex (Masson et al., 2013), a major challenge is modeling lateral water fluxes, which create spatially different soil moisture conditions (as at the Zackenberg site) that subsequently can have a pronounced impact on the ground thermal regime.

As pointed out by Gubler et al. (2011), spatially distributed in situ data sets are required to calibrate and validate spatially distributed modeling schemes in heterogeneous permafrost landscapes. These should capture the variability of the different environmental factors governing the ground thermal regime, which in many permafrost landscapes will require a significant effort with potentially dozens of measurement locations. However, such work is a crucial prerequisite to improve the ability of modeling schemes to simulate the distribution of the ground thermal regime and its response to present and future changes.

\subsection{From model results to permafrost landscape development}

Most real-world applications of permafrost models assume non-interacting grid cells with spatially constant soil properties. Consequently, permafrost degradation in model studies (e.g., Westermann et al., 2013) is generally described as talik formation manifested in the temperature profile of a onedimensional grid cell. While this is indeed observed in in- 
strumented boreholes, it can be accompanied by significant changes in the hydrological regime by thawing of hydrological barriers or the formation of new aquifers. Most operational permafrost models are not capable of predicting such developments, which is a significant limitation for sound predictions on the permafrost-carbon feedback. For the study area, Elberling et al. (2013) demonstrated that the potential $\mathrm{CO}_{2}$ emissions from carbon-rich wetland soils strongly depend on the future hydrological regime of the wetland, with a drying of the wetland leading to significantly faster carbon turnover. Furthermore, thawing of excess ground ice can entirely modify the landscape, e.g., through thermokarst or thaw slumps which can be hotspots of greenhouse gas emissions and thus modify the carbon budget of an entire permafrost landscape. While excess ground ice has been included in land-surface models (Lee et al., 2014), the considerable spatial variability and the interplay between excess ice thaw, microtopography and fluxes of energy and water represent major unresolved challenges.

From the perspective of model development, a simple increase of the spatial resolution seems a prerequisite to resolve such shortcomings in the next generation of permafrost models. At a $10 \mathrm{~m}$ resolution, this study captured two important aspects which can be seen as part of the "thermal signature" of the permafrost landscape in Zackenberg: (a) the differences in maximum thaw depth between different ecosystem classes and (b) the spatial variability of ground temperatures to a large extent caused by spatially variable snow depths. Compared to large-scale (as in Daanen et al., 2011) or pointscale simulations (as in Hollesen et al., 2011), it provides a far more detailed (though still incomplete) assessment of the possible development of the Zackenberg permafrost landscape, which can be better linked to studies on the future ecosystem carbon turnover (e.g., Elberling et al., 2013). For modeling of large spatial domains, a grid cell size of $10 \mathrm{~m}$ is generally not feasible due to computation power. Statistical representations of small-scale variability are a promising approach to overcome this problem, as recently explored by Fiddes et al. (2015) and Gisnås et al. (2014).

\section{Conclusions}

This study presents numerical simulations of present and future ground thermal conditions for a transect across the lowlying parts of the high-Arctic Zackenberg valley in northeast Greenland. At the modeling scale of $10 \mathrm{~m}$, the governing factors for the ground thermal regime are accounted for in a deterministic way. This involves snow depth (derived from a blowing snow model), ground properties (derived from an NDVI-based ecosystem classification) and surface properties (derived from empirical correction factors for summer surface temperature based on NDVI). Past and future climate trends for the general area are derived from in situ records and a regional climate model. The following conclusions can be drawn from this study:

- The model approach can capture the measured differences in maximum thaw depth between different ecosystem classes encountered in the area. The simulated ground temperatures are in agreement with available borehole measurements.

- The modeled average ground temperatures increase by about $4{ }^{\circ} \mathrm{C}$ until 2100 but generally remain below $0^{\circ} \mathrm{C}$. However, a few model grid cells with topographically induced snow drifts feature positive average $1 \mathrm{~m}$ temperatures in single years after 2060 .

- The modeled maximum thaw depths increase moderately in all ecosystem classes, with the lowest value of $0.2 \mathrm{~m}$ for the wetland sites.

- The spatial variability of the average ground temperatures at $1 \mathrm{~m}$ depth within a distance of a few kilometers is between 3 and $5{ }^{\circ} \mathrm{C}$ and thus on the order of the projected increase of ground temperatures until the end of this century. Therefore, both modeling and in situ monitoring of the ground thermal regime may provide an incomplete assessment of present and future permafrost thaw if they are restricted to one or a few points within an area.

The study exemplifies that grid-based simulations at coarse scales with only one or few model realizations cannot fully account for the spatial variability of the ground thermal regime in many permafrost areas. They are hence not capable of correctly projecting the onset of permafrost thaw at the required scale to trigger transformative landscape changes due to erosion and hydrological processes. Despite the complex model approach, the projections of the future ground thermal regime are associated with considerable uncertainties related to a variety of environmental factors, which exemplifies the need for intensified process studies in permafrost environments.

Acknowledgements. We gratefully acknowledge the financial support for this study from the Danish National Research Foundation (CENPERM DNRF100), the European Union FP7ENVIRONMENT project PAGE21 under contract no. GA282700 as well as the Faculty of Science at the University of Copenhagen. Also, we extend our gratitude to the Greenland Ecosystem Monitoring (GEM) programme, funded by the Danish Ministry for Climate, Energy and Building, for providing access to data. Finally, a warm thanks to staff from GeoBasis and BioBasis at Zackenberg research station and the students involved in field measurements. Two anonymous reviewers greatly contributed to improving the manuscript.

Edited by: S. Gruber 


\section{References}

Bay, C.: Vegetation mapping of Zackenberg valley, Northeast Greenland, Danish Polar Center and Botanical Museum, University of Copenhagen, 75 pp., 1998.

Brown, J., Hinkel, K., and Nelson, F.: The circumpolar active layer monitoring (CALM) program: research designs and initial results, Polar Geogr., 24, 166-258, 2000.

Christensen, J. H., Christensen, O. B., Lopez, P., van Meijgaard, E., and Botzet, M.: The HIRHAM 4 regional atmospheric climate model, Scientific Report 96-4, Danish Meteorological Institute, 51 pp., 1996.

Clarke, L., Edmonds, J., Jacoby, H., Pitcher, H., Reilly, J., and Richels, R.: Scenarios of greenhouse gas emissions and atmospheric concentrations, Sub-report of Synthesis and Assessment Product - 2.1. Climate Change Science Program and the Subcommittee on Global Change Research, Washington DC, 2007.

Clauser, C. and Huenges, E.: Thermal conductivity of rocks and minerals, AGU Reference Shelf, 3, 105-126, 1995.

Cosenza, P., Guerin, R., and Tabbagh, A.: Relationship between thermal conductivity and water content of soils using numerical modelling, European J. Soil Sci., 54, 581-588, 2003.

Côté, J. and Konrad, J.-M.: A generalized thermal conductivity model for soils and construction materials, Canad. Geotechn. J., 42, 443-458, 2005.

Daanen, R. P., Ingeman-Nielsen, T., Marchenko, S. S., Romanovsky, V. E., Foged, N., Stendel, M., Christensen, J. H., and Hornbech Svendsen, K.: Permafrost degradation risk zone assessment using simulation models, The Cryosphere, 5, 10431056, doi:10.5194/tc-5-1043-2011, 2011.

Dall'Amico, M., Endrizzi, S., Gruber, S., and Rigon, R.: A robust and energy-conserving model of freezing variably-saturated soil, The Cryosphere, 5, 469-484, doi:10.5194/tc-5-469-2011,2011.

Elberling, B., Jakobsen, B. H., Berg, P., Søndergaard, J., and Sigsgaard, C.: Influence of vegetation, temperature, and water content on soil carbon distribution and mineralization in four High Arctic soils, Arct. Antarct. Alp. Res., 36, 528-538, 2004.

Elberling, B., Tamstorf, M. P., Michelsen, A., Arndal, M. F., Sigsgaard, C., Illeris, L., Bay, C., Hansen, B. U., Christensen, T. R., Hansen, E. S., Jakobsen, B. H., and Beyens, L.: Soil and plant community-characteristics and dynamics at Zackenberg, Adv. Ecol. Res., 40, 223-248, 2008.

Elberling, B., Christiansen, H. H., and Hansen, B. U.: High nitrous oxide production from thawing permafrost, Nature Geosci., 3, 332-335, 2010.

Elberling, B., Michelsen, A., Schädel, C., Schuur, E. A., Christiansen, H. H., Berg, L., Tamstorf, M. P., and Sigsgaard, C.: Long-term $\mathrm{CO}_{2}$ production following permafrost thaw, Nature Clim. Change, 3, 890-894, 2013.

Ellebjerg, S. M., Tamstorf, M. P., Illeris, L., Michelsen, A., and Hansen, B. U.: Inter-annual variability and controls of plant phenology and productivity at Zackenberg, Adv. Ecol. Res., 40, 249273, 2008.

Endrizzi, S., Gruber, S., Dall'Amico, M., and Rigon, R.: GEOtop 2.0: simulating the combined energy and water balance at and below the land surface accounting for soil freezing, snow cover and terrain effects, Geosci. Model Dev., 7, 2831-2857, doi:10.5194/gmd-7-2831-2014, 2014.

Fiddes, J. and Gruber, S.: TopoSUB: a tool for efficient large area numerical modelling in complex topography at sub-grid scales,
Geosci. Model Dev., 5, 1245-1257, doi:10.5194/gmd-5-12452012, 2012.

Fiddes, J. and Gruber, S.: TopoSCALE v.1.0: downscaling gridded climate data in complex terrain, Geosci. Model Dev., 7, 387-405, doi:10.5194/gmd-7-387-2014, 2014.

Fiddes, J., Endrizzi, S., and Gruber, S.: Large-area land surface simulations in heterogeneous terrain driven by global data sets: application to mountain permafrost, The Cryosphere, 9, 411-426, doi:10.5194/tc-9-411-2015, 2015.

Fredskild, B. and Mogensen, G. S.: Zero Line: Final Report 1997: a Description of the Plant Communities Along the ZERO Line from Young Sund to the Top of Aucellabjerg and the Common Plant Communities in the Zackenberg Valley, Northeast Greenland, Greenland Botanical Survey \& Botanical Museum, University of Copenhagen, 1997.

Gisnås, K., Westermann, S., Schuler, T. V., Litherland, T., Isaksen, K., Boike, J., and Etzelmüller, B.: A statistical approach to represent small-scale variability of permafrost temperatures due to snow cover, The Cryosphere, 8, 2063-2074, doi:10.5194/tc-82063-2014, 2014

Goodrich, L.: The influence of snow cover on the ground thermal regime, Canad. Geotech. J., 19, 421-432, 1982.

Gubler, S., Fiddes, J., Keller, M., and Gruber, S.: Scaledependent measurement and analysis of ground surface temperature variability in alpine terrain, The Cryosphere, 5, 431-443, doi:10.5194/tc-5-431-2011, 2011

Gubler, S., Endrizzi, S., Gruber, S., and Purves, R. S.: Sensitivities and uncertainties of modeled ground temperatures in mountain environments, Geosci. Model Dev., 6, 1319-1336, doi:10.5194/gmd-6-1319-2013, 2013.

Hansen, B. U., Sigsgaard, C., Rasmussen, L., Cappelen, J., Hinkler J., Mernild, S. H., Petersen, D., Tamstorf, M. P., Rasch, M., and Hasholt, B.: Present-day climate at Zackenberg, Adv. Ecol. Res., 40, 111-149, 2008.

Hazeleger, W., Severijns, C., Semmler, T., Stefanescu, S., Yang, S., Wang, X., Wyser, K., Dutra, E., Baldasano, J. M., Bintanja, R., Caballero, R., Dutra, E., Ekman, A., Christensen, J., van den Hurk, B., Jimenez, P., Jones, C., Kallberg, P., McGrath, R., de Miranda, P., Molteni, F., van Noije, T., Palmer, T., Rodriguez Camino, E., Schmith, T., Selten, T., Sterl, A., Tapamo, H., and Viterbo, P.: EC-earth: a seamless earth-system prediction approach in action, B. Am. Meteor. Soc., 91, 1357-1363, 2010.

Hazeleger, W., Wang, X., Severijns, C., Ştefănescu, S., Bintanja, R., Sterl, A., Wyser, K., Semmler, T., Yang, S., Van den Hurk, B., van Noije, T., van der Linden, E., and van der Wiel, K.: ECEarth V2. 2: description and validation of a new seamless earth system prediction model, Clim. Dynam., 39, 2611-2629, 2012.

Hinkler, J., Pedersen, S. B., Rasch, M., and Hansen, B. U.: Automatic snow cover monitoring at high temporal and spatial resolution, using images taken by a standard digital camera, Int. J. Remote Sens., 23, 4669-4682, 2002.

Hipp, T., Etzelmüller, B., Farbrot, H., Schuler, T., and Westermann, S.: Modelling borehole temperatures in Southern Norway - insights into permafrost dynamics during the 20th and 21st century, The Cryosphere, 6, 553-571, doi:10.5194/tc-6-553-2012, 2012.

Hock, R.: Temperature index melt modelling in mountain areas, J. Hydrol., 282, 104-115, 2003.

Hollesen, J., Elberling, B., and Jansson, P. E.: Future active layer dynamics and carbon dioxide production from thawing permafrost 
layers in Northeast Greenland, Global Change Biol., 17, 911926, 2011.

Hugelius, G., Bockheim, J. G., Camill, P., Elberling, B., Grosse, G., Harden, J. W., Johnson, K., Jorgenson, T., Koven, C. D., Kuhry, P., Michaelson, G., Mishra, U., Palmtag, J., Ping, C.-L., O'Donnell, J., Schirrmeister, L., Schuur, E. A. G., Sheng, Y., Smith, L. C., Strauss, J., and Yu, Z.: A new data set for estimating organic carbon storage to $3 \mathrm{~m}$ depth in soils of the northern circumpolar permafrost region, Earth Syst. Sci. Data, 5, 393-402, doi:10.5194/essd-5-393-2013, 2013.

Jafarov, E. E., Marchenko, S. S., and Romanovsky, V. E.: Numerical modeling of permafrost dynamics in Alaska using a high spatial resolution dataset, The Cryosphere, 6, 613-624, doi:10.5194/tc6-613-2012, 2012.

Jansson, P. and Karlberg, L.: COUP manual: Coupled heat and mass transfer model for soil-plant-atmosphere systems, Technical manual for the CoupModel, 1-453, 2004.

Klene, A. E., Nelson, F. E., Shiklomanov, N. I., and Hinkel, K. M.: The $\mathrm{N}$-factor in natural landscapes: Variability of air and soilsurface temperatures, Kuparuk river basin, Alaska, USA, Arctic, Antarctic, and Alpine Research, 140-148, 2001.

Koch, L. and Haller, J.: Geological map of Clavering Ø (74 Ø 2), Meddelelser om Grønland, Bd. 18.3, 1965.

Langen, P. L., Mottram, R. H., Christensen, J. H., Boberg, F., Rodehacke, C. B., Stendel, M., van As, D., Ahlstrøm, A. P., Mortensen, J., Rysgaard, S., Petersen, D., Svendsen, K. H., Aðalgeirsdóttir, G., Cappelen, J., Quantifying energy and mass fluxes controlling Godthåbsfjord freshwater input in a $5 \mathrm{~km}$ simulation (1991-2012), J. Climate, doi:10.1175/JCLI-D-14-00271.1, in press, 2015.

Langer, M., Westermann, S., Heikenfeld, M., Dorn, W., and Boike, J.: Satellite-based modeling of permafrost temperatures in a tundra lowland landscape, Remote Sens. Environ., 135, 12-24, 2013.

Lawrence, D. M., Slater, A. G., and Swenson, S. C.: Simulation of present-day and future permafrost and seasonally frozen ground conditions in CCSM4, J. Climate, 25, 2207-2225, 2012.

Lee, H., Swenson, S. C., Slater, A. G., and Lawrence, D. M.: Effects of excess ground ice on projections of permafrost in a warming climate, Environ. Res. Lett., 9, 124 006, doi:10.1088/17489326/9/12/124006, 2014.

Lehning, M., Völksch, I., Gustafsson, D., Nguyen, T. A., Stähli, M., and Zappa, M.: ALPINE3D: a detailed model of mountain surface processes and its application to snow hydrology, Hydrol. Proc., 20, 2111-2128, 2006.

Liston, G. E.: Interrelationships among snow distribution, snowmelt, and snow cover depletion: Implications for atmospheric, hydrologic, and ecologic modeling, J. Appl. Meteorol., 38, 1474-1487, 1999.

Liston, G. E. and Sturm, M.: A snow-transport model for complex terrain, J. Glaciol., 44, 498-516, 1998.

Liston, G. E.: Local advection of momentum, heat, and moisture during the melt of patchy snow covers, J. Appl. Meteorol., 34, 1705-1715, 1995.

Liston, G. E.: Representing subgrid snow cover heterogeneities in regional and global models, J. Climate, 17, 1381-1397, 2004.

Liston, G. E. and Elder, K.: A distributed snow-evolution modeling system (SnowModel), J. Hydrometeorol., 7, 1259-1276, 2006a.
Liston, G. E. and Elder, K.: A meteorological distribution system for high-resolution terrestrial modeling (MicroMet), J. Hydrometeorol., 7, 217-234, 2006b.

Liston, G. E. and Hall, D. K.: An energy-balance model of lake-ice evolution, J. Glaciol., 41, 373-382, 1995.

Liston, G. E. and Hiemstra, C. A.: A simple data assimilation system for complex snow distributions (SnowAssim), J. Hydrometeorol., 9, 989-1004, 2008.

Liston, G. E. and Hiemstra, C. A.: The Changing Cryosphere: PanArctic Snow Trends (1979-2009), J. Climate, 24, 5691-5712, 2011.

Liston, G. E. and Mernild, S. H.: Greenland freshwater runoff. Part I: A runoff routing model for glaciated and non-glaciated landscapes (HydroFlow), J. Climate, 25, 5997-6014, 2012.

Liston, G. E., Pielke, R. A., and Greene, E. M.: Improving firstorder snow-related deficiencies in a regional climate model, J. Geophys. Res.-Atmos., 104, 19559-19567, 1999.

Liston, G. E., Haehnel, R. B., Sturm, M., Hiemstra, C. A., Berezovskaya, S., and Tabler, R. D.: Instruments and methods simulating complex snow distributions in windy environments using SnowTran-3D, J. Glaciol., 53, 241-256, 2007.

Lucas-Picher, P., Wulff-Nielsen, M., Christensen, J. H., Aðalgeirsdóttir, G., Mottram, R., and Simonsen, S. B.: Very high resolution regional climate model simulations over Greenland: Identifying added value, J. Geophys. Res.-Atmos., 117, D02108, doi:10.1029/2011JD016267, 2012.

Masson, V., Le Moigne, P., Martin, E., Faroux, S., Alias, A., Alkama, R., Belamari, S., Barbu, A., Boone, A., Bouyssel, F., Brousseau, P., Brun, E., Calvet, J.-C., Carrer, D., Decharme, B., Delire, C., Donier, S., Essaouini, K., Gibelin, A.-L., Giordani, H., Habets, F., Jidane, M., Kerdraon, G., Kourzeneva, E., Lafaysse, M., Lafont, S., Lebeaupin Brossier, C., Lemonsu, A., Mahfouf, J.-F., Marguinaud, P., Mokhtari, M., Morin, S., Pigeon, G., Salgado, R., Seity, Y., Taillefer, F., Tanguy, G., Tulet, P., Vincendon, B., Vionnet, V., and Voldoire, A.: The SURFEXv7.2 land and ocean surface platform for coupled or offline simulation of earth surface variables and fluxes, Geosci. Model Dev., 6, 929-960, doi:10.5194/gmd-6-929-2013, 2013.

Mastepanov, M., Sigsgaard, C., Dlugokencky, E. J., Houweling, S., Ström, L., Tamstorf, M. P., and Christensen, T. R.: Large tundra methane burst during onset of freezing, Nature, 456, 628-630, 2008.

Meltofte, H., Christensen, T. R., Elberling, B., Forchhammer, M. C., and Rasch, M.: High-arctic ecosystem dynamics in a changing climate, 40, 1-563, Elsevier Academic Press Inc., San Diego, 2008.

Merzlaya, G., Stepanov, A., and Fedorov, A. Y.: Growing potatoes above the arctic circle, Russ. Agric. Sci., 34, 373-376, 2008.

Mesinger, F., DiMego, G., Kalnay, E., Mitchell, K., Shafran, P. C., Ebisuzaki, W., Jovic, D., Woollen, J., Rogers, E., Berbery, E. H., Ek, B. M., Fan, Y., Grumbine, R., Higgins, W., Li, H., Lin, Y., Manikin, G., Parrish, D., and Shi, W.: North American regional reanalysis, B. Am. Meteor. Soc., 87, 343-360, 2006.

Mick, A. H. and Johnson, H. A.: Soil resources and agricultural development in Alaska, Arctic, 7, 236-248, 1954.

Osterkamp, T. and Romanovsky, V.: Evidence for warming and thawing of discontinuous permafrost in Alaska, Permafrost Periglac. Proc., 10, 17-37, 1999. 
Pedersen, S. H., Liston, G. E., Tamstorf, M. P., WestergaardNielsen, A., and Schmidt, N. M.: Quantifying episodic snowmelt events in Arctic ecosystems, Ecosystems, doi:10.1007/s10021015-9867-8, 2015.

Rae, J. G. L., Aðalgeirsdóttir, G., Edwards, T. L., Fettweis, X., Gregory, J. M., Hewitt, H. T., Lowe, J. A., Lucas-Picher, P., Mottram, R. H., Payne, A. J., Ridley, J. K., Shannon, S. R., van de Berg, W. J., van de Wal, R. S. W., and van den Broeke, M. R.: Greenland ice sheet surface mass balance: evaluating simulations and making projections with regional climate models, The Cryosphere, 6, 1275-1294, doi:10.5194/tc-6-1275-2012, 2012.

Schuur, E. A. G., Bockheim, J., Canadell, J. G., Euskirchen, E., Field, C. B., Goryachkin, S. V., Hagemann, S., Kuhry, P., Lafleur, P. M., Lee, H., Mazhitova, G., Nelson, F. E., Rinke, A., Romanovsky, V. E., Shiklomanov, N., Tarnocai, C., Venevsky, S., Vogel, J. G., and Zimov, S. A.: Vulnerability of permafrost carbon to climate change: Implications for the global carbon cycle, Bioscience, 58, 701-714, 2008.

Schuur, E. A., Vogel, J. G., Crummer, K. G., Lee, H., Sickman, J. O., and Osterkamp, T. E.: The effect of permafrost thaw on old carbon release and net carbon exchange from tundra, Nature, 459, 556-559, 2009.

Smith, S. J. and Wigley, T.: Multi-gas forcing stabilization with MiniCAM, The Energy Journal, 373-392, 2006.

Stendel, M. and Christensen, J.: Impact of global warming on permafrost conditions in a coupled GCM, Geophys. Res. Lett., 29, 10-1-10-4, doi:10.1029/2001GL014345, 2002.

Stendel, M., Romanovsky, V. E., Christensen, J. H., and Sazonova, T.: Using dynamical downscaling to close the gap between global change scenarios and local permafrost dynamics, Global Planet. Change, 56, 203-214, 2007.

Tamstorf, M., Illeris, L., Hansen, B., and Wisz, M.: Spectral measures and mixed models as valuable tools for investigating controls on land surface phenology in high arctic Greenland, BMC Ecology, 7, p. 9, doi:10.1186/1472-6785-7-9, 2007.

Thomson, A. M., Calvin, K. V., Smith, S. J., Kyle, G. P., Volke, A., Patel, P., Delgado-Arias, S., Bond-Lamberty, B., Wise, M. A., Clarke, L. E., et al.: RCP4.5: a pathway for stabilization of radiative forcing by 2100, Clim. Change, 109, 77-94, 2011.

Vionnet, V., Brun, E., Morin, S., Boone, A., Faroux, S., Le Moigne, P., Martin, E., and Willemet, J.-M.: The detailed snowpack scheme Crocus and its implementation in SURFEX v7.2, Geosci. Model Dev., 5, 773-791, doi:10.5194/gmd-5-773-2012, 2012.
Walker, D., Jia, G., Epstein, H., Raynolds, M., Chapin Iii, F., Copass, C., Hinzman, L., Knudson, J., Maier, H., Michaelson, G., et al.: Vegetation-soil-thaw-depth relationships along a lowarctic bioclimate gradient, Alaska: synthesis of information from the ATLAS studies, Permafrost Periglac. Proc., 14, 103-123, 2003.

Walter, K., Zimov, S., Chanton, J., Verbyla, D., and Chapin III, F. Methane bubbling from Siberian thaw lakes as a positive feedback to climate warming, Nature, 443, 71-75, 2006.

Wang, S., Li, Z., and Wu, J.: The state of the art and new subjects of highway research in permafrost regions of China, J. Glaciol. Geocryol., 25, 471-476, 2003.

Wang, S., Huang, X., and Hou, S.: Numerical analyses of pavement deformation and stress in permafrost regions, J. Glaciol. Geocryol., 28, 217-222, 2006.

Westermann, S., Boike, J., Langer, M., Schuler, T. V., and Etzelmüller, B.: Modeling the impact of wintertime rain events on the thermal regime of permafrost, The Cryosphere, 5, 945-959, doi:10.5194/tc-5-945-2011, 2011.

Westermann, S., Schuler, T., Gisnås, K., and Etzelmüller, B.: Transient thermal modeling of permafrost conditions in Southern Norway, The Cryosphere, 7, 719-739, doi:10.5194/tc-7-7192013, 2013.

Winstral, A., Elder, K., and Davis, R. E.: Spatial snow modeling of wind-redistributed snow using terrain-based parameters, J. Hydrometeorol., 3, 524-538, 2002.

Wise, M., Calvin, K., Thomson, A., Clarke, L., Bond-Lamberty, B. Sands, R., Smith, S. J., Janetos, A., and Edmonds, J.: Implications of limiting $\mathrm{CO}_{2}$ concentrations for land use and energy, Science, 324, 1183-1186, 2009.

Yen, Y.-C.: Review of thermal properties of snow, ice and sea ice, CRREL Rep., 81-10, 1981.

Zhang, Y.: Spatio-temporal features of permafrost thaw projected from long-term high-resolution modeling for a region in the Hudson Bay Lowlands in Canada, J. Geophys. Res.-Earth Surf., 118, 542-552, 2013.

Zhang, Y., Li, J., Wang, X., Chen, W., Sladen, W., Dyke, L., Dredge, L., Poitevin, J., McLennan, D., Stewart, H., Kowalchuk, S., Wu, W., Kershaw, P., and Brook, R. K.: Modelling and mapping permafrost at high spatial resolution in Wapusk National Park, Hudson Bay Lowlands, Canad. J. Earth Sci., 49, 925-937, 2012.

Zhang, Y., Wang, X., Fraser, R., Olthof, I., Chen, W., Mclennan, D., Ponomarenko, S., and Wu, W.: Modelling and mapping climate change impacts on permafrost at high spatial resolution for an Arctic region with complex terrain, The Cryosphere, 7, 11211137, doi:10.5194/tc-7-1121-2013, 2013. 